\title{
A AGROINDÚSTRIA E A GERAÇÃO DE EMPREGO NO MUNICÍPIO DE VERA CRUZ, ESTADO DE SÃO PAULO
}

\section{ARMANDO VAZ SAMPAIO}

Engenheiro Agrônomo

\section{Orientadora: PROFa DRa ZILDA PAES DE BARROS MATTOS}

Dissertacăo apresentada à Escola Superior de Arriculinurs "Luiz de Queiroz", da Universidade de Sảo Paulo, pare obtenção do Titulo de Mestre en Agronomis, Área de Concentrafäo: Ecomomia Agréria

PIRACICABA

Estado de Sảo Paulo - Brasil

setembro - 1995 
Dados Internacionais de Catalogação na Publicação (CIP)

DIVISAO DE BIBLIOTECA E DOCUMENTACAO - Campus "Luiz de QueirOz"/USP

Sampaio, Armando Vaz

A agroindistria e a geraçăo de emprego no municipio de Vera Cruz, Estado de Săo Paulo. Piracicaba, 1995.

79p. ilus.

Diss. (Mestre) - ESALO

B ibl iografia.

1. Incústria agrícola - Emprego - Vera Cruz, SP I. Escola superior de Agricultura Luiz de Queiroz, Piracicaba

CDD 338.9 


\section{A AGROINDÚSTRIA E A GERAÇÃO DE EMPREGO NO MUNICIPIO DE VERA CRUZ, ESTADO DE SÃO PAULO}

\section{ARMANDO VAZ SAMPAIO}

\section{Aprovado em 10/10/95}

Comissão julgadora:

Profa DRa Zilda Paes de Barros Mattos

DR. Jose Gasparino Fitho

Prof Dr. Pedro Valentim Fitho
ESALQ/USP

ITAL

ESALQ/USP




Aos meus pais

pelo apoio e estumulo

A meus inmåos

pelo incentivo

Dedico 


\section{AGRADECIMENTOS}

A professora Dra. Zilda Paes de Barros Mattos pela dedicada orientação, incentivo e paciência demonstrada durante a realização deste trabalho.

Ao professor Dr. Pedro Valentim Marques pelas sugestðes oferecidas durante o término deste trabalho.

Aos professores, funcionários e amigos do Departamento de Economia e Sociologia Rural da ESALQ/USP, pela colaboração e amizade durante o decorrer do curso.

Ao pesquisador Dr.José Gasparino Filho, do Setor de Engenharia e Projetos do ITAL, pela colaboraçăo na elaboraçăo do projeto industrial da agroindústria.

A pesquisadora Laura Ap. Savitci, do Setor de Mercadologia do ITAL, pelo auxdlio na elaboraçăo do fluxo de caixa do projeto.

Ao pesquisador Manuel Carmo Vieira, do Setor de Informática do ITAL, pelo auxilio na compilação dos dados.

Ao Departamento de Agronomia da Universidade Estudal de Londrina (UEL), pela liberação para poder terminar este trabalho.

Aos colegas do curso, Mauricio e Marcos, pela agradável convivência e amizade durante o decorrer do curso. 


\section{SUMARIO}

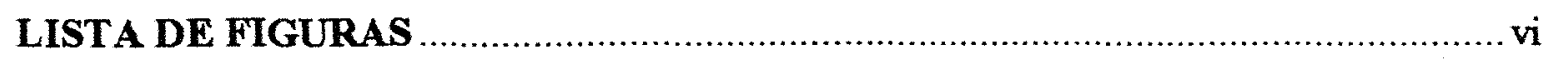

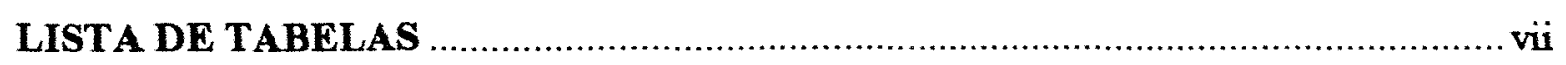

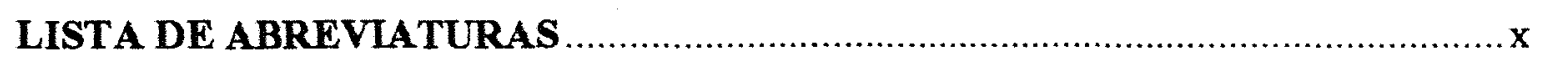

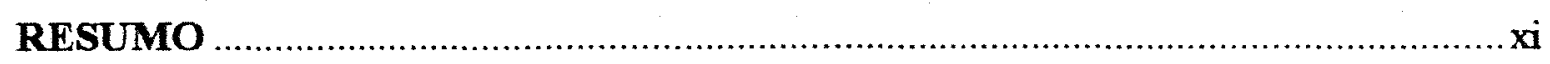

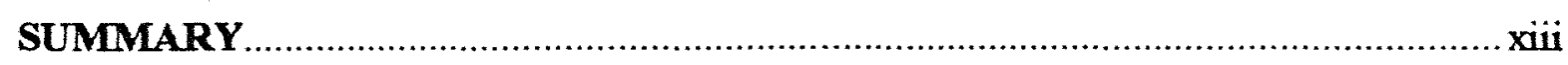

1. INTRODUÇÃO

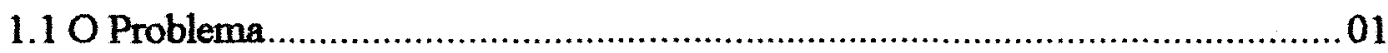

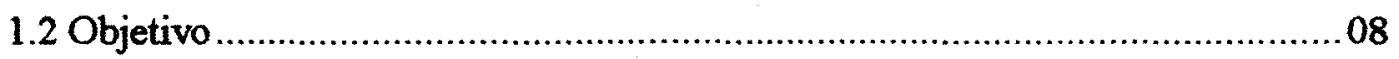

\section{REVISÃO DE LITERATURA}

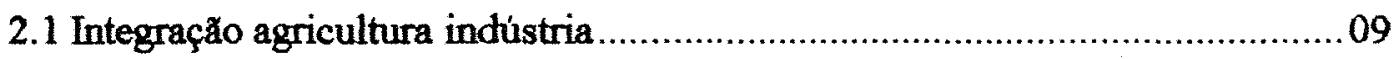

2.20 desenvolvimento do CAI no Brasil ..................................................... 14

2.3 A agroindústria e o desenvolvimento .................................................... 16

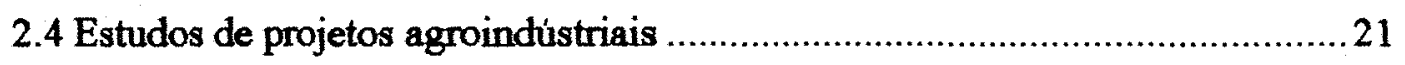

\section{METODOLOGIA}

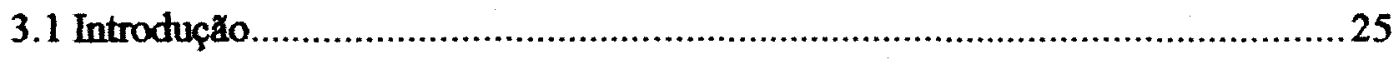

3.2 Capacidade Minima da Unidade Processadora ......................................25

3.3 Metódo de Avaliação Econômica

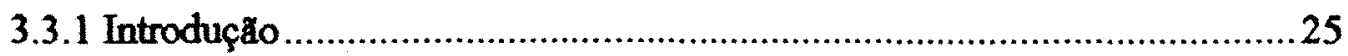

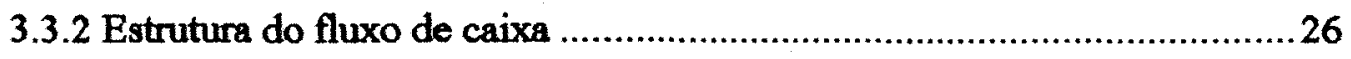

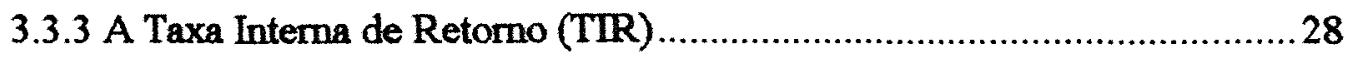

3.3.4 Determinaçăo do ponto de equilibrio e do lucro bruto anual da unidade de processamento................................................. 34

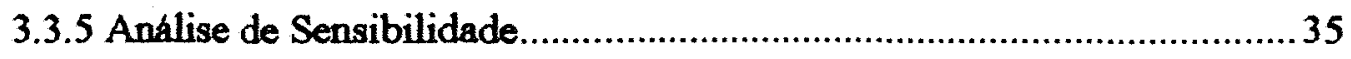

3.4 Impacto do projeto de investimento sobre o nivel de emprego

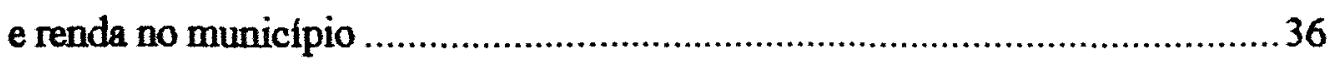




\section{RESULTADOS ECONÔMICOS}

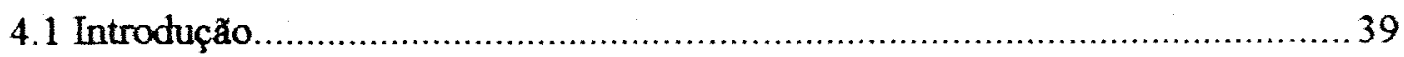

4.2 Capacidade Minima da Unidade Processadora .......................................... 39

4.3 Estrutura do Fluxo de Caixa

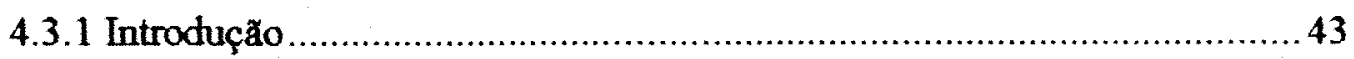

4.3.2 Estimativa do Investimento Fixo e Capital de giro para a industrialização do maracujá e do abacaxi................................................44

4.3.3 Resultado do caso-base e Análise de Sensibilidade …..............................46

4.4 Estimativa da Receita Total, Custo Total e Unitário e do

Lucro Bruto anual do empreendimento

4.4.1 Estimativa do Custo Total e Unitário dos

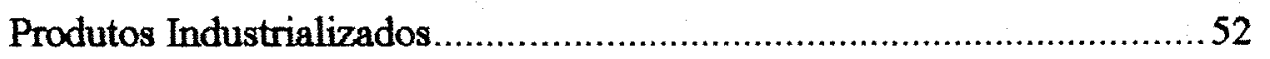

4.4.2 Estimativa da Receita Total e do Lucro Bruto anual

do empreendimento e do seu ponto de equilibrio .....................................55

4.5 Impacto sobre o nivel de emprego e renda no municipio.................................58

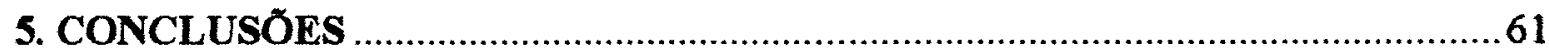

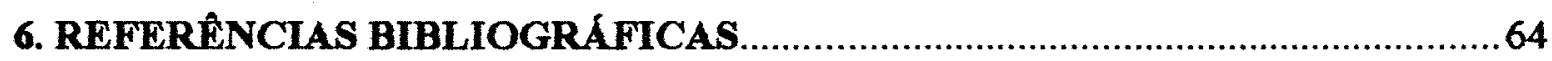

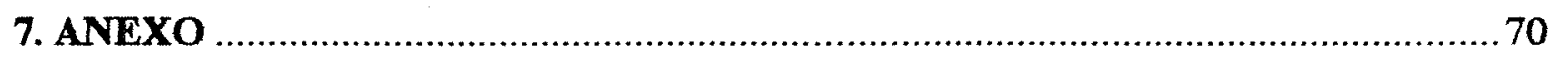




\section{LISTA DE FIGURAS}

Figura no

Psgina

1 - Determinação gráfica da taxa interna de retorno (TIR)

2 - Fluxograma quantitativo básico para produção de suco de maracujá congelado

3 - Fluxograma quantitativo básico para produçăo de suco de abacaxi congelado

4 - Determinação do ponto de equilibrio (PE) da indústria de sucos congelados em termos de capacidade instalada 


\section{LISTA DE TABELAS}

Tabela no

Pagina

1 - Preços Internacionais do café beneficiado, em dolares-americanos, 1985/1986 - 1992/93

2 - Evolução dos indices de preços reais, de café beneficiado, 1981-1992

3 - Participação da População Economicamente Ativa e do valor da produção em porcentagem, por setor econômico no Municipio de Vera Cruz, SP.

4 - População nural e urbana de Vera Cruz, Estado de São Paulo, 1980-1991

5 - Participação percentual das principais DIRAs (Divisão Regional Agricola) e quantidadede produzida de maracujá no Estado de São Paulo, 1986/87-1990/91

6 - Crescimento da produção e da participação relativa dos diversos agregados do complexo agroindustrial norte americano, 1910 e 1965

7 - Distribuiçåo do valor adicionado entre os agregados no complexo brasileiro entre 1970 e 1980

8 - Investimento de US\$ 1 milhăo na melhoria da capacidade industrial em Oklahoma em 1970 e seu impacto no nivel de emprego de curto, médio e longo prazo e seus multiplicadores

9 - Custo de investimento para a prođução de 100 empregos no curto, médio e longo prazo em Oklahoma, 1970

10 - Coeficientes de geraçăo de empregos diretos e indiretos, por atividade, para cada milhão de cruzeiros investidos

11 - Estimativa do Fluxo de Caixa

12 - Distribuição quantitativa e percentual da produção da unidade industrial por produto 
13 - Necessidade de embalagem (tambores de $220 \mathrm{~kg}$ com saco plástico de $100 \mu \mathrm{m}$ duplo)

14 - Estimativa do investimento fixo necessário para a implantaçăo de uma unidade industrial de processamento de suco de maracujá e de abacaxi congelados

15 - Estimativa do Capital de giro necessário para a implantação de uma unidade industrial de processamento de suco de maracujá e de abacaxi congelados

16 - Estrutura do Fluxo de Caixa

17 - Estimativa do Fuxo de Caixa do Caso Base

18 - Resultados das análises de sensibilidade da TIR a variaçðes nos valores de diversos componentes do fluxo de caixa da unidade de industrialização do suco de maracujá e de abacaxi congelados

19 - Estimativa do custo fixo anual necessário para a implantação de uma unidade industrial de processamento de suco de maracujá e de abacaxi congelados

20 - Estimativa do custo variável anual incorrido na etapa de processamento do suco de maracujá e de abacaxi congelados

21 - Necessidade de maracujá em função da percentagem da utilização da capacidade da indústria

22 - Necessidade de área plantada de maracujá, em hectares, em função da percentagem de fruta destinada à indústria e da produtividade da cultura (100\% da capacidade instalada da fábrica)

23 - Necessidade de área plantada de maracujá, em hectares, em funçăo da percentagem de fruta destinada a indústria e da produtividade da cultura ( $90 \%$ da capacidade instalada da fábrica)

24 - Necessidade de área plantada de maracujá, em hectares, em função da percentagem de fruta destinada à indústria e da produtividade da cultura ( $80 \%$ da capacidade instalada da fábrica)

25 - Necessidade de área plantada de maracuja, em hectares, em funçăo da percentagem de fruta destinada à indústria e da produtividade da cultura ( $70 \%$ da capacidade instalada da fabrica) 
26 - Estimativas em investimento em obras civil 71

27 - Lista dos equipamentos de processamento de suco de maracujá e de 72 abacaxi congelados

28 - Lista dos equipamentos auxiliares da unidade industrial 73

29 - Lista dos equipamentos de laboratório para a unidade industrial 74

30 - Vidraria para o laboratório

31 - Lista de veiculos para unidade industrial 76

32 - Lista de móveis e instalações de escritório 77

$\begin{array}{ll}33 \text { - Estimativa de måo de obra fixa mensal } & 78\end{array}$

34 - Estimativa de måo de obra variável mensal 79 


\section{LISTA DE ABREVIATURAS}

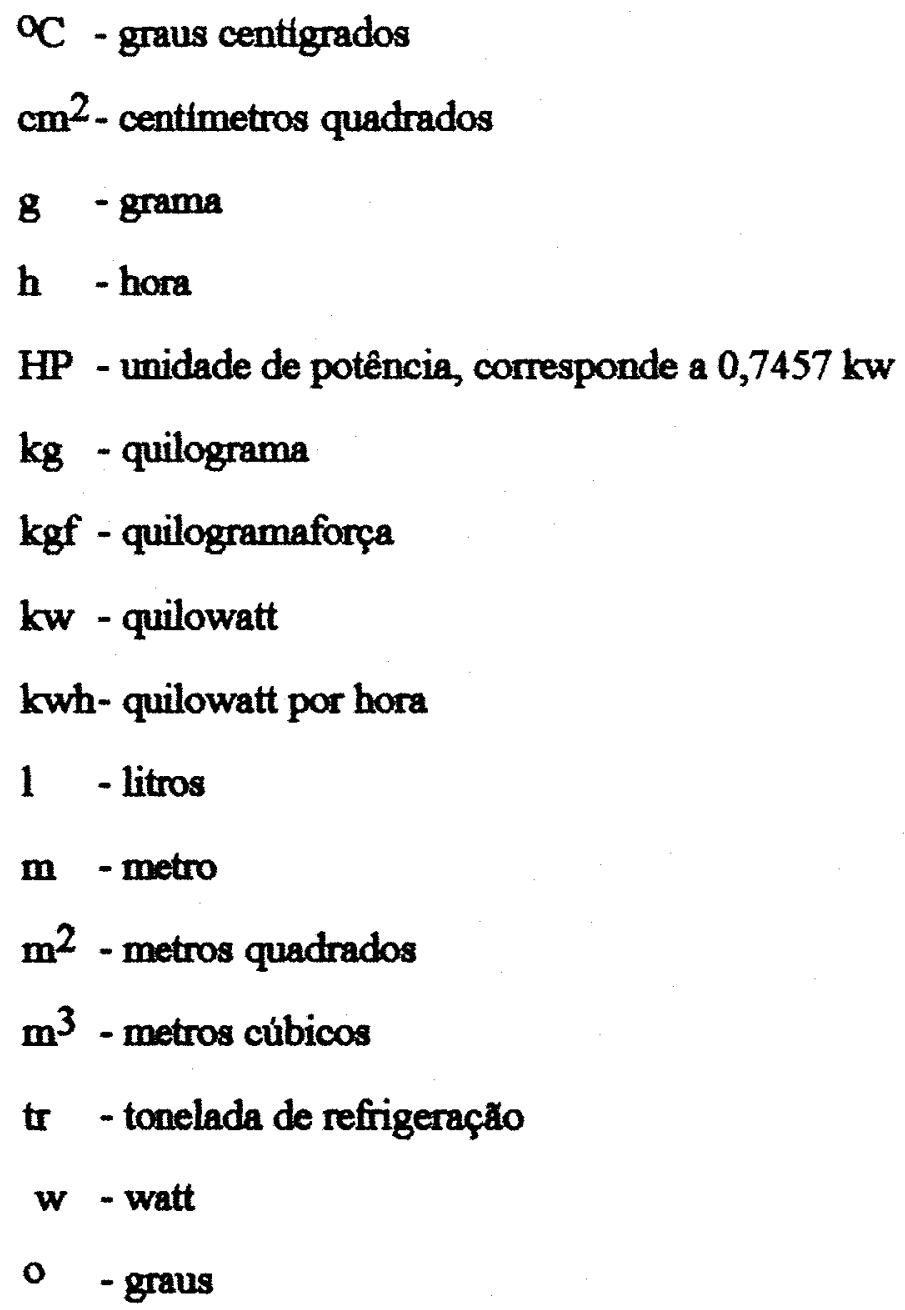




\title{
A AGROINDÚSTRIA E A GERAÇÃO DE EMPREGO NO MUNICIPIO DE VERA CRUZ, ESTADO DE SÃO PAULO
}

\author{
Autor: Armando Vaz Sampaio \\ Orientadora : PROFa DRa : Zilda Paes de Barros Mattos
}

\section{RESUMO}

O objetivo do presente trabalho foi verificar a viabilidade econômica da implantação de uma unidade agroindústrial de suco de maracujá no município de Vera Cruz, Estado de São Paulo, visando dessa forma diminuir a migraçăo nural urbana, aumentar o número de empregos no campo e incentivar a produçăo dos pequenos produtores no referido municipio.

Com o aumento da produção de maracujá no municipio de Vera Cruz, os produtores perceberam a necessidade de comercializar melhor a sua produçăo. Dessa maneira, eles decidiram fundar a Associaçăo de Fruticultores de Vera Cruz (AFRUVEC), onde o maracujá comercializado é destinado a dois mercados: um de fruta "in natura" e o outro para a indústria de suco congelado. Com o sucesso da AFRUVEC, os associados levantaram a hipótese de eles próprios processarem o maracujá, o que possibilita adicionar valor ao produto, indo de encontro às tendéncias do mercado atual. 
Em função da quantidade de matéria-prima disponivel no municipio, foi projetada a unidade industrial que terá a capacidade de processar $2500 \mathrm{~kg}$ de matéria-prima por hora. Foi encontrado para a fábrica um ponto de equilibrio (P.E.) de $65 \%$ da capacidade instalada. O critério utilizado para verificar a viabilidade econômica do projeto foi a taxa interna de retorno (TIR), cujo valor encontrado foi $25,72 \%$ para o caso-base, valor esse suficiente para cobrir o custo do capital para a empresa ( 8 a $12 \%$ a.a).

Foi verificado que a interrelação da indútria com o setor agricola é alto, pois irá possibilitar a oferta de aproximadamente 1700 empregos por ano na área agricola quando é utilizada $100 \%$ da capacidade instalada da fábrica.

Foi também feita uma análise de sensibilidade para verificar o efeito das variações de alguns itens que são importantes na estrutura de custo do empreendimento sobre a TIR, mostrando-se esta mais sensivel à variação do preço do produto final, do custo da matéria-prima e da percentagem da capacidade instalada da fábrica. 


\title{
THE AGRIBUSINESS FIRM AND THE JOB CREATION IN THE "MUNICIPIO" OF VERA CRUZ, STATE OF SAO PAULO
}

\author{
Armando Vaz Sampaio \\ Adviser: PROF $\underline{\text { a }}$ DR : Zilda Paes de Barros Mattos
}

\section{SUMMARY}

Thia study verified the economic feasibility of a juice industry of passion fruit in the city of Vera Cruz, State of São Paulo, Brazil. The results showed that the juice industry may contribute to decrease nural migration to urban areas by increasing the number of jobs and agricultural production in that region.

With the increase of passion fruit production in Vera Cruz, a Farmer's Association (AFRUVEC) was founded, in order to improve marketing operations. The fruits marketed by AFRUVEC are sent to two different markets: "in natura" and a frozen juice industry. Given the success of that association, producers are considering industrializing the juice themselves, increasing the added product value, a worldwide market tendency nowadays. 
The industrial plant was projected with a capacity of $2,500 \mathrm{~kg}$ of raw material per hour, according to the availability of raw material in Vera Cruz. The results showed that $65 \%$ of plant capacity was the breakeven point. The criterion used to verify the industrial plant feasibity was the internal rate of return (IRR), wich had value of $25,72 \%$ for the base-case, above industry's capital cost ( 8 to $12 \%$ a year). The linkage between passion fruit industry and rural sector was strong, with additional 1,700 jobs creation a year, in the rural sector, considering $100 \%$ of plant capacity. The sensitivity analisys showed that variation on final product price, raw material cost and percent of plant capacity had the greatest effects on IRR. 


\section{1) INTRODUÇÃO}

\section{1) O Problema}

O número de pequenos produtores e trabalhadores rurais que migraram da zona rural para a zona urbana nas últimas décadas, tem sido elevado. O município de Vera Cruz, no Estado de São Paulo, é um dos muitos locais do País onde a migração rural-urbana assume proporções assustadoras com consequências prejudiciais para os migrantes e para a população do município de um modo geral. Este estudo trata da viabilidade econômica da instalação de uma indústria de processamento de suco de maracujá e de abacaxi no município, como política atenuante desse fluxo migratório que vem ocorrendo nos últimos anos. Nesse sentido, autores como CHIRIBOGA e PLAZA (1993), e LAUSCHNER (1986) e muitos outros, afirmam que o desenvolvimento de uma agroindústria em uma regiäo poderá solidificar a agricultura à medida que esta receberá assistência técnica por parte da agroindústria na produção da matéria-prima.

Quando observamos o histórico do município, verificamos que o café era uma cultura que predominava na região. Mas, a queda de seus preços desde o início de 1987 (Tabelas 1 e 2), juntamente com o problema de estiagem que os produtores enfrentaram naquele período e um aumento do custo de produção, levaram a um forte desestímulo à produção dessa cultura (BAPTISTELA, 1991).

A cultura do café sempre foi uma atividade importante na DIRA (Divisão Regional Agrícola) de Marília, onde se situa o município de Vera Cruz No entanto, ao analisar a área plantada com café nessa regiåo, observa-se que a cultura perdeu importância, ou seja, passou de 9,25\% para 6,56\% em relação à área total da DIRA, respectivamente em 1970/71 e 1987/88. As culturas que mais cresceram em área plantada neste período foram a cana para industria, a soja e o trigo. Embora a área de pastagem tenha diminuido, continua 
Tabeln 1 - Precos Internscionsis de cafe beneficiado, em doleres norte-americanos, sacos de $60 \mathrm{Kg}$

\begin{tabular}{ccccc}
\hline Anos & Arabica sem lavar & Colombia suave & $\begin{array}{l}\text { Outros tipos de } \\
\text { suaves }\end{array}$ & Tipo Robusta \\
\hline $1982 / 83$ & 236,45 & 210,11 & 187,63 & 160,36 \\
1983 & 190,33 & 188,81 & 175,59 & 165,49 \\
1984 & 199,83 & 196,84 & 192,33 & 184,21 \\
1985 & 202,35 & 207,83 & 194,08 & 161,83 \\
1986 & 308,25 & 293,39 & 256,99 & 197,11 \\
1987 & 141,83 & 164,60 & 149,72 & 136,45 \\
1988 & 162,45 & 1401 & 180,13 & 126,81 \\
1989 & 130,67 & 142,67 & 142,67 & 101,33 \\
1990 & 110,67 & 129,33 & 118,67 & 73,33 \\
1991 & 97,33 & 120,00 & 113,33 & 66,67 \\
1992 & 76,00 & 90,67 & 85,33 & 58,67 \\
\hline
\end{tabular}

1 nso cotado

Fonte : Fao - Situacion Y Perspectivas de Los Produrtos bisicos - 1985/86- 1992/93

Tabela 2 - Evoluçăo dos indices de preços reais 1 , de cafte beneficiado recebido

\begin{tabular}{cccc}
\multicolumn{5}{c}{ pelos produtores do Estado de Sko Paulo, } & 1981-1992. & \\
\hline Anos & Mínimo & Máximo & Medio \\
\hline 1981 & 91 & 119 & 100 \\
1982 & 98 & 105 & 101 \\
1983 & 79 & 109 & 93 \\
1984 & 83 & 110 & 99 \\
1985 & 122 & 208 & 150 \\
1986 & 259 & 363 & 310 \\
1987 & 59 & 217 & 100 \\
1988 & 57 & 74 & 65 \\
1989 & 42 & 106 & 76 \\
1990 & 43 & 59 & 52 \\
1991 & 43 & 55 & 48 \\
1992 & 35 & 52 & 41 \\
\hline
\end{tabular}

Deflator: IGP/DI - FGV

Foate : Informaçes Econsimicas IEA, novembro 1993, p.15.

sendo a primeira atividade em área, na regino. Tal alteraçăo incidiu fortemente sobre o comportamento da populaçato regional, uma vez que a erradicaçato do cafe dispensou um numero significativo de trabalhadores e a passagem para criação de gado e outras linhas de produçăo agricola culminou em nivel de absorçăo de pessoal ocupado muito restrito, promovendo assim deslocamentos de contigentes do quadro rural para as proximidades dos núcleos urbanos onde procuram conseguir emprego (GONÇALVES et alii, 1990).

Na DIRA de Marllia ocorreu uma alteraçăo da populaçăo regional onde se observa uma reduçăo no ntvel de emprego rural; em 1979 este representava 9,92\% do total de emprego rural no Estado de Săo Paulo e em 1989 passou para 6,67\%, sendo que o 
número total de empregos rurais nesses dois anos para o Estado de Såo Paulo, praticamente não foi alterado (CARVALHO et alï, 1992). O município de Vera Cruz, pertencente à DIRA de Marilia e distante cerca de $\mathbf{4 0 0} \mathrm{Km}$ de Så Paulo, foi duramente afetado pela modificação da utilização do solo e pela crise do café vivida pela regira, juntamente com outros municipios cuja fonte de receita é basicamente o setor agropecuário, como pode ser observado na Tabela 3.

Tabela 3 - Participação da População Economicamente Ativa e do Valor da Produção em porcentagem, por setor econômico no Município de Vera Cruz, Estado de São Paulo, 1980.

\begin{tabular}{|c|c|c|c|c|c|c|}
\hline \multicolumn{4}{|c|}{ Populacão Economicamente Ativa } & \multicolumn{3}{|c|}{ Valor de Producão } \\
\hline Primário & Secundário & Terciário & Outros & Primário & Secundário & Terciário \\
\hline 52,59 & 12,96 & 30,80 & 1,35 & 22,58 & 54,83 & 19,59 \\
\hline
\end{tabular}

Fonte: Informaçōes Econômicas, S.P., v.23, No 12, 1993,p.32.

Com a recessão econômica vivida pelo País na década de 80 e a crise vivida pela agricultura, especialmente no que diz respeito às culturas tradicionais como o café, ocorreu um aumento do número de famílias em estado de indigência no município de Vera Cruz (e em muitos outros mumicípios no Estado de Sæ̃o Paulo), chegando a alcançar 16,47\% da população total (MARTIN, 1993). Verifica-se um saldo populacional negativo de $-3,52 \%$ de 1980 a 1991 para o município. A população rural decresceu 33\%, enquanto hourve aumento na população urbana (Tabela 4), provocando uma elevação do número de familias em estado de indigência.

Tabela 4- População rural e urbana de Vera Cruz Estado de Săo Paulo, 1980 e 1991

\begin{tabular}{|c|c|c|c|}
\hline \multirow{2}{*}{ Populaç̃o } & \multicolumn{2}{|c|}{ Anos } & \multirow[t]{2}{*}{ Variapă \% } \\
\hline & 1980 & 1991 & \\
\hline Urbana & 6869 & 8003 & $+16,50$ \\
\hline Rural & 4560 & 3024 & $-33,68$ \\
\hline Total & 11429 & 11027 & $-3,52$ \\
\hline
\end{tabular}

Fonte : IBGE, Sinopse Preliminar do Censo Demográfico, 1991.

Esta crise de emprego e renda vivida pelo município de Vera Cruz e pela Região da Nova Alta Paulista não é um caso particular somente dessa regiāo, e nem é um 
fenômeno que tenha ocorrido somente nesses últimos anos. E sim um processo que vem ocorrendo desde a aceleraçăo da industrializaçăo brasileira, que deixou de incentivar a agricultura quando comparada com outros setores da economia, especialmente nas regióes menos dinâmicas do Estado de Să Paulo. A concentraçăo da propriedade da terra, o uso intensivo de capital, bem como a falta de recursos públicos e infraestrutura social e econômica de apoio a produçżo no meio rural, certamente foram alguns dos fatores que contribuiram para a intensificaçăo da imigraçăo rural (BARROS, 1993).

Devemos lembrar que năo foi somente a crise da cultura do caft que levou a essa situaçăo a regilio de Nova Alta Paulista; contribuiram tambem para que a regiăo chegasse a tal nivel de paralisia, o aumento da área plantada de cana-de-açúcar (incentivo do PROALCOOL) e da soja (preços internacionais favoráveis). Tais culturas aumentaram a concentraçŭo fundiária, uma vez que possuem uma acentuada economia de escala, além de contribuir para o aumento da sazonalidade da demanda por mäo-de-obra. Somando-se a isso, existem na regižo extensas treas de pastagem com pouca necessidade de mllo-de-obra (GONÇALVEZ, 1990). Todos esses fatores contribuem para a diminuiçăo do número de pequenos produtores rurais, incentivando ainda mais a emigraçăo rural.

Como tentativa para a diminuiçăo da gravidade desse quadro, a fruticultura desponta como a atividade mais adequada para reverter tal situaçăo, particularmente a cultura do maracujá. A regiåo possui condiçoes edafo-climéticas para a implantaçlo dessa atividade, a qual, alem de possuir uma demanda com elasticidade-renda alte, alta rentabilidade e rapido retomo para o produtor, requer grande quantidade de măo-de-obra, geralmente cultivada em pequenas áreas (SATO et alii, 1992), podendo se tomar um fator favoravel a fixaçăo do pequeno produtor no campo. Nos ultimos anos, a produçlo de maracuja na regilo teve um crescimento muito acentuado, como pode ser verificado na Tabela 5.

A maior parte da produçăto de maracujé do municipio de Vera Cruz visa ao mercado de fruta "in natura", sendo o restante enviado para uma inctustria de suco em 
Dracena , Estado de Săo Paulo. Recentemente, os produtores de maracuja se organizaram e fundaram, com o apoio do projeto "Desenvolvimento Rural Integrando, DRI" 1 ,a Associação de Fruticultores de Vera Cruz (AFRUVEC), para a comercializaçăo da fruta, eliminando dessa maneira o intermediário, o que provocou um ganho real para os produtores 2.

Tabela 5 - Participacio percentual das principais DIRAs ( Divisio Regional Agricola) e quantidade produzida de marncujic en toneladis no Estado de S5o Paulo, 1986/87 a $1990 / 91$.

\begin{tabular}{|c|c|c|c|c|c|c|c|c|}
\hline \multirow[t]{2}{*}{ Anos } & \multicolumn{2}{|c|}{ Registro } & \multicolumn{2}{|c|}{ Presidente Prodente } & \multicolumn{2}{|c|}{ Marilia } & \multicolumn{2}{|c|}{ Outros } \\
\hline & $\%$ & $\mathbf{t}$ & $\%$ & $t$ & $\%$ & $t$ & $\%$ & $t$ \\
\hline $\begin{array}{l}1986 / 87 \\
1987 / 88 \\
1988 / 89 \\
1989 / 90 \\
1990 / 91\end{array}$ & $\begin{array}{l}80,18 \\
69,16 \\
58,50 \\
49,16 \\
39,81\end{array}$ & $\begin{array}{r}7465 \\
28925 \\
10071 \\
8412 \\
10627\end{array}$ & $\begin{array}{l}11,38 \\
10,95 \\
17,19 \\
17,68 \\
19,92\end{array}$ & $\begin{array}{l}1060 \\
1413 \\
2959 \\
3025 \\
5317\end{array}$ & $\begin{array}{l}3,40 \\
12,35 \\
8,82 \\
14,07 \\
16,52\end{array}$ & $\begin{array}{r}317 \\
1594 \\
1518 \\
2408 \\
4409\end{array}$ & $\begin{array}{l}5,04 \\
7,54 \\
15,49 \\
19,09 \\
23,76\end{array}$ & $\begin{array}{r}469 \\
973 \\
2667 \\
3267 \\
6343\end{array}$ \\
\hline
\end{tabular}

Fonte : Informaçoes Econbmicas, V.22, n.6, junho 1992.

A agroindústria vem adquirindo importância cada vez maior no processo de desenvolvimento rural, pela possibilidade de trazer maior valor agregado a produçăo agropecuária no meio rural, além da capacidade de reunir a economia do campo ao sistema industrial, multiplicando as potencialidades de geraçăo de renda e de emprego, fortalecendo assim os mercados e pólos de desenvolvimento local e regional. Com o sucesso da AFRUVEC, os proprios associados levantaram a possibilidade de processar o maracujá no próprio municipio. Tal iniciativa vai de encontro com o ponto de vista de muitos autores que consideram a agroinctustria como a força motora para a dinamizaçăo econômica de uma regiăo, pois leva a um aumento do nưmero de emprego, um maior encadeamento da agricultura com os outros setores da economia, e uma melhoria da base técnica. Esta última teria grande importancia principalmente para os pequenos produtores rurais, pois devido à falta de recursos públicos, o Serviço de Extensăo Rural do Estado fica impossibilitado de atender a esse tipo de produtor, além de produzir um produto com valor adicionado maior

\footnotetext{
${ }^{1}$ Este projeto faz perte do programe do NACE-DRI da Universidade de Sto Paula, no Campus de Piracicabe, Estado de 8\%o Paulo.

${ }^{2}$ Informecseo obtida pessoalmente do Presidente da Associaçito dos Fruticultores da regilio de Vera Cruz
} 
entre outras coisas (CHIRIBOGA e PLAZA ,1993; LAUSCHNER, 1986 e YOUNG e CAMPLIGLIA, 1991).

Para ALBUQUERQUE e GARCIA (1988), os setores agricola e agroindustrial devem produzir alimentos "in natura" e processados em grande volume e a baixo custo para atender ao conjunto da populaçăo urbana que no Brasil cresce a taxas elevadas. Além disso, esses setores podem contribuir com a geraçăo de postos de trabalho em quantidade, para incorporar parte dos atuais desempregados e dos subempregados existentes no mercado de trabalho. Comparativamente a outros setores, a agroindústria requer montantes de capital por unidade de protuçăo substancialmente menores e possibilidades de se estabelecer em escala menor e tecnologia menos intensiva em capital, aumentando assim as possibilidades de emprego e de melhoria na distribuiç̆o de renda e da terra.

A agroindústria tem sido, tanto nos paises desenvolvidos como nos subdesenvolvidos, a soluçăo para o problema do desemprego na agricultura segundo KLATZMANN (citado por SILVEIRA, 1990). A idéia é levar à indústria a força de trabalho e as matérias-primas localmente disponiveis, a fim de evitar as migraçöes para as grandes cidades. Quanto maior o poder de encadeamento de um setor, tanto para a frente como para tras, maior serd o seu efeito na economia, o o setor de produtos alimentares se encontra entre os quatros maiores setores que possuem altos indice de ligaçăo para trás e para a frente (GUILHOTO, 1992).

Uma boa articulaçăo do setor agropecuário com o industrial é fundamental para que ambos sejam beneficiados. A garantia de matéria-prima para processamento em quantidade, qualidade e custos compativeis, pode ter como contrapartida da incústria, o complemento de crédito, fornecimento de insumos e assistência técnica. Assim, as agroindústrias tendem a influenciar o padrto de produçăto e do utilizaçăo do excendente do setor agropecuário, donde surge a necessidade de regulaçăo dos canais de comercializaçăo para resguardar os interesses dos agricultores. A escolha das agroindustrias a serem 
instaladas deve levar em conta o impacto que provocarăo na economia da regiro, atraves da ligaçăo com atividades preexistentes ou criando um canal de crescimento ou polo de crescimento. Năo se deve esquecer que um dos motivos fundamentais para a interiorizaçăo da indústria é o desejo de proporcionar trabalho produtivo aos desempregados das áreas rurais; outro é criar centros dispersos de inovaçăo e mudanças económicas e sociais nas cidades do interior (SILVEIRA e LEITE, 1990).

De acordo com os estudos de BROW (1986), as agroindustrias podem desempenhar nos paises subdesenvolvidos as seguintes funçodes: a) absorver excedentes agricolas e atender ds necessidades do aumento da populaçăo urbana; b) criar valor adicionado ds matérias-primas e empregos a um custo menor do que muitas outras indústrias; c) instalar-se em localidades nas quais outras indústrias nåo tenham condiçōes de viabilidade e d) contribuir para descentralizar a posse da propriedade industrial e a interiorizaçăo do desenvolvimento.

LAUSCHNER (1981) conclui em seu trabalho que "... o pais subdesenvolvido que tem pouca capacidade de investimentos e que necessita fixar o homem no campo năo pode dar-se ao luxo de dedicar-se a produção agropecuária e deixar que o exterior incustrialize o produto. Isto exigiria grandes investimentos para gerar pouca renda e pouco emprego. É a agroindústria o principal agente de fortalecimento das microregides no pais, o caminho principal de fixaçăo do homem ao campo e o setor que viabiliza a geraçăo de muito mais renda e emprego que os mesmos investimentos gerariam na aplicaçăo direta no setor agropecuário".

Fica claro, assim, a importancia de se estudar a viabilidade económica de uma indústria de suco de maracujá e de abacaxi no municipio de Vera Cruz, no Estado de Såo Paulo, o que será o principal objetivo desse estudo. 


\section{2) Objetivos}

O objetivo principal deste trabalho é analisar a viabilidade econômica da implantaçăo de uma industria produtora de suco de maracujá e de abacaxi no municipio de Vera Cruz, como sendo uma maneira de acelerar o seu desenvolvimento econômico.

Especificamente pretende-se :

a) definir uma escala de produçăo apropriada à regiăo;

b) determinar o ponto de nivelamento (ou de equilibrio) da unidade de processamento;

c) determinar a taxa interna de retorno (TIR) do investimento;

d) fazer uma análise de sensibilidade das variáveis do projeto de investimento e

e) avaliar o impacto do projeto no nivel de emprego. 


\section{2) REVISÃO DE LITERATURA}

Para verificar a importância do papel da agrointústria no processo de desenvolvimento econômico de uma regiåo, é preciso primeiro analisar a agricultura de uma maneira intersetorial e para isso esta seção será dividida em quatro partes, onde a primeira parte tratara das origens do inter-relacionamento da agricultura com os outros setores da economia e o processo de modernização da agricultura. Na segunda parte, descreve-se a crescente importância da indústria de processamento (agregado III) na dinâmica agriculturaindústria no Brasil, além de apontar a importancia da açăo do Estado no sucesso de alguns setores do Complexo Agroindustrial (CAI). Na terceira parte, såo apresentados trabalhos que investigam a influência da instalaçăo de uma unidade processadora de matéria-prima agricola no desenvolvimento regional e seu impacto no aumento do nível de emprego e renda na regiåo. E, finalmente, na quarta e última parte, são revistos alguns trabalhos que tratam especificamente da viabilidade econômica da instalaçăo de uma unidade agroincustrial.

\section{1) A integraçæo agricultura indústria.}

O setor agropecuário pode ser estudado em três enfoques: o primeiro, é o estudo pelo destino da produçăo, mercado interno ou mercado externo, que seria o estudo pelo lado da demanda. O segundo enfoque seria dado pelo lado da oferta, considerando a formação do preço que condiciona a evoluçăo da produção agricola; e finalmente, o terceiro enfoque, estuda a agricultura de uma maneira intersetorial, onde tenta definir quais são os setores dinamizadores, e com isso propor politicas que visem incentivar esses setores chaves (RAMALHO, 1988).

Quando se procura estudar a agricultura de uma forma intersetorial, sem a clássica dicotomia campo/cidade ou a clássica divisăo da economia em setor primário, secundário e terciário, pensa-se logo na relaçăo dinâmica que existe entre a agricultura e a 
indústria. Mas, essa relação năo é recente, podendo-se dizer que teve inicio com a Revoluçăo Industrial ocorrida na Inglaterra no século XVII, pois a agricultura fornecia matéria-prima requerida pelas industrias de $1 \mathrm{a}$ e liberava força de trabalho que era absorvida pelas indústrias. Logo, o processo, longe de ser dicotômico, foi complementar, o que não significa harmônico, pois a måo-de-obra liberada pelo campo nåo era imediatamente absorvida por parte das indústrias (CASTANHO, 1985).

Quando se estuda o setor agroindústrial, é necessário pensar nesse setor dentro de um mesmo sistema, e nåo apenas na agricultura como fonte fornecedora de matéria-prima e de aquisição de produtos manufaturados. De fato esta relação existe, mas não é tăo simples assim. Essa idéia năo é nova, pois foram os fisiocratas no sec. XVIII que estabeleceram tal concepção, cujo representante principal foi QUESNAY em seu "Tableau economique de $1766^{\prime \prime}$. Esta obra tentava definir as diversas relaçóes entre os setores da economia. Uma quantificaç̆o mais rigorosa dessas relaçőes seria facilitada com a construçăo da primeira matriz insumo-proctuto, elaborada por LEONTIEF, relativo ao ano de 1919, embora publicada apenas em 1936 e que representava a economia norte-americana atraves de uma matriz de 46 linhas e 46 colunas (ALBUQUERQUE e GARCIA, 1988).

Esta obra, publicada em 1936 influenciou vários trabalhos posteriores, inclusive o trabalho pioneiro de DAVIS e GOLDBERG (1957), que criou o conceito de "agribusiness", como sendo "a soma de todos as operaçסes que envolvem a manufatura e distribuiçăo de insumos para a unidade de produçăo agricola, as operaçós produtivas na unidade produtora agricola propriamente dita e o armazenamento, processamento e distribuiçăo dos produtos agricolas e seus subprodutos (p.16)".

Ao se observar os dados da economia norte-americana entre 1910 e 1965, elaborados por DAVIS e GOLDBERG (1957), verifica-se uma queda da participaçăo relativa do agregado II (produçăo dos agricultores) e um aumento do agregado I (produçăo de insumos agricolas) e principalmente do agregado III (armazenagem, processamento e 
distribuiçăo final), com relação ao seu complexo agroindustrial. Pode-se dizer também que as relaçőes entre os agregados se intensificaram nesse intervalo de tempo (Tabela 6).

Tabela 6 - Crescimento da produçăo e da participaça relativa dos diversos agregados do complexo agroindustrial norte americano, 1910 e 1965.

\begin{tabular}{|c|c|c|c|c|c|c|}
\hline \multirow[t]{2}{*}{ Agregado } & \multicolumn{2}{|c|}{ Em bilhoes de dolares } & \multicolumn{2}{|c|}{ Em porcentagem } & \multicolumn{2}{|c|}{ Evoluctio } \\
\hline & 1910 & 1965 & 1910 & 1965 & 1910 & 1965 \\
\hline I - Produçăo insumos agricolas & 1,0 & 32 & 11 & 21 & 1 & 32,0 \\
\hline II - Produçăo dos agricultores & 4,8 & 16 & 54 & 11 & 1 & 3,3 \\
\hline $\begin{array}{l}\text { III-Armazenagem, procesaanmento, } \\
\text { distribuiçio final, etc }\end{array}$ & 3,1 & 102 & 35 & 68 & 1 & 32,9 \\
\hline Total do complexo agroindustrial & 8,9 & 150 & 100 & 100 & 1 & 16,9 \\
\hline
\end{tabular}

Foate : Davis,John \& Goldberg, Ray A, 1957, p.14

ARAÚJO et alii (1991) ao estudarem as mudanças no complexo agroindustrial brasileiro com relaçăo a repartiçăo de seu valor adicionado, verificaram que ocorreu uma grande mudança no periodo compreendido entre 1970 e 1980 (Tabela 7 ).

Tabeln 7. Distribuiçlo do valor adicionado entre os agregados no complexs agroindurrial brasileiro entre $1970 \mathrm{e}$ 1980.

\begin{tabular}{|c|c|c|}
\hline \multirow[t]{2}{*}{ Agregado } & \multicolumn{2}{|c|}{ Ano } \\
\hline & 1970 & 1980 \\
\hline & \multicolumn{2}{|c|}{$(\mathrm{em} \%)$} \\
\hline I - Produçăo insumos agricolas & 12 & 11 \\
\hline II - Produçío dos agricultores & 38 & 28 \\
\hline II - Armazenagem, processamento, distribuiçlo final, etc & so & 61 \\
\hline III - Total do complexwo sgroindustrial. & 100 & 100 \\
\hline
\end{tabular}

Fonte: Arajjo et alii, p. 37. 
Pode-se concluir que a tendência observada na economia norte-americana e brasileira é um processo que vem ocorrendo em todos os países, revelando que o agregado III é o elemento dinâmico no desenvolvimento do complexo agroindustrial, e a pouca participação da agricultura revela ser resultado de um longo e contínuo processo de modernização. Para MULLER (1989) e KAGEYAMA et alii (1990), modernização da agricultura é o resultado da interação entre industrialização do campo ${ }^{1}$, agroindustrializaçãa ${ }^{2}$ dos produtos agrários e mudanças sociais ${ }^{3}$ e políticas entre os grupos sociais. Neste sentido, a constituição do CAI é produto da modernização e a sua manutenção e expansão se constituem no principal vetor da modernização.

A forma de difusão do progresso tecnológico não depende somente da diferença de preços relativos dos insumos dos recursos produtivos, mas também das inovações tecnológicas produzidas pelos segmentos à montante e à jusante da atividade agrícola (PAIVA, 1975 e MULLER, 1989). Dessa maneira, a interdependência da atividade agrícola com a indústria fornecedora de insumo condicionará o padrão tecnológico de produção. Por outro lado, a relação da agricultura com a indústria compradora de matériaprima influenciará na organização da produção, porque estará determinando épocas de aquisição da matéria-prima e a sua quantidade (RAMALHO 1988). No estudo da agricultura de uma maneira intersetorial, existem duas correntes, a do complexo agroindústrial e a do sistema agroalimentar. A primeira corrente considera o complexo agroindústrial de uma forma mais abrangente, sendo que estudos mais específicos foram realizados por MULLER (1989), SORJ (1980), RAMALHO (1988) e STREETER (1991), entre outros. Já a segunda corrente considera o complexo agroindustrial de uma forma mais restrita, cujos trabalhos

\footnotetext{
${ }^{1}$ Industrialização do campo significa a existência de uma forte interdependência entre a agricultura e indústria para a agricultura.

${ }^{2}$ Agroindustrualizaçăa significa a existência de uma forte interdependência entre agricultura e a indústria beneficiadora e processadora.

${ }^{3}$ Estas mudanças sociais se referem à mudança nas formas de trabalho, extinção do colonato, emergência e expansão dos boias-frias e empregados permanentes, etc.
} 
especificos foram realizados por LIFSCHITS e PROCHNIK, (1987), HAGUENAUER (1988), SCARLATO e RUBIO (1991), LEITE (1990) e FARINA, (1988).

Quando falamos de CAI ou "Agribusiness" devemos lembrar que isso também envolve diferentes formas de coordenação de mercado. Um tipo de coordenação de mercado seria a cooordenação vertical, que ocorre quando existe uma certa direção e controle entre os diversos segmentos do sistema de produção e comercialização. A coordenação vertical pode ser alcançada através da integração vertical que é o controle dos diversos estágios de produção realizado pelas transações de mercado ou através de contratos formais (BABB, 1992 e KING, 1992).

É comum na agricultura diversas instituiçð̃es exercerem uma coordenação vertical. As cooperativas de produtores rurais que estão espalhadas em diversas regióes, não deixam de ser uma forma de integraçåo vertical, pois exercem uma certa coordenação de mercado principalmente no que diz respeito aos insumos que os cooperados utilizam e aos produtos que eles produzem. As relações contratuais das indústrias de aves, súnos, frutas e hortaliças, são exemplos de coordenação vertical que é exercida através de contratos, ao invés das próprias indústrias serem responsáveis pela produção da matéria-prima. Para as indústrias processadoras e para os varejistas, estes contratos asseguram o fornecimento da matériaprima em quantidade e qualidade (KING, 1992).

O desenvolvimento da coordenação vertical está mudando significativamente a organização e 0 ambiente administrativo da agricultura e realça a importância das ligações entre a coordenaçåo vertical e a estrutura financeira. Este desenvolvimento leva a diferentes perspectivas na organização das empresas agrícolas e da própria definição de empresa, onde se nota uma nova abordagem que se faz com relação a função de produção tradicional (BARRY, 1992).

Para a economia das organizaçōes, a definição de empresa passa da função de produçăo tradicional para uma relaçăo contratual, na qual a empresa é um agente de contratos ("nexus of contracts"), uma estrutura de direção ("governance structure") e um 
agente de controle de seu ativo ("locus of asset ownrship and control"). A fronteira entre a empresa e o mercado é então determinado pela soma dos custos administrativos e pelo custo de transaçăo. Para definir essas fronteiras compara-se a internalizaçăo desses custos com os custos de transaçăo do mercado. A queståo sobre coordenaçăo vertical resume-se, assim, em saber se a internalizaçåo do controle de estágios sucessivos da produçăo resulta na reduçăo da soma dos custos administrativos, do custo de transaçăo e dos "agency costs" (BARRY, 1992).

\section{2) O desenvolvimento do CAI no Brasil}

A integraçăo da agricultura com a indústria, no Brasil, remonta ds origens de sua colonizaçăo (a partir dos engenhos de açúcar, a produção agricola de exportaçăo era, em diversos graus, processada dentro do pais). Já as indústrias produtoras de insumos e maquinas para a agricultura e processamento de alimentos em grande escala para o mercado intemo, såo fenômenos contemporâneos, cujas formaçôes podem ser localizadas em torno das últimas decadas (SORJ, 1980). No periodo entre 1960-1980, observa-se que a dinâmica da atividade agropecuária brasileira passou a ser significativamente determinada pelo setor integrado indústria/agriculture, responsáveis pela denominaçăo de complexos agroindustriais (MULLER, 1989).

ALBUQUERQUE e GARCIA (1988), descrevem a importancia do setor processador de matéria-prima agropecuária, a partir de dados da matriz de relaçóes intersetoriais de 1970 da economia brasileira, da seguinte maneira: ..."56\% da produçăo agricola văo para a agroindústria de processamento e transformaçăo (de ordem de 2,8 bilhóes de dólares em 1970), 17\% vto para o consumo final, distribuidos pelos setores de comercializaçăo de bens de consumo, $15 \%$ săo utilizados dentro do próprio subsetor, $5 \%$ văo para a exportaç⿰丿⺄⿱㇒⿴囗⿱一一⿱宀八人 e $7 \%$ văo para outros setores". 
Como se tem observado no resto do mundo, o negócio agricola tem apresentado crescimento expressivo na geraçăo de riqueza e emprego no Brasil. Em 1988, os complexos agroindustriais contribuiram com $34 \%$ do PIB, que foi de US\$ 280,3 bilhoes. Destacaram-se a proctucăo vegetal ( 19\%), a producto animal ( $10 \%$ ), os insumos e fatores de produçăo ( 8\%) e os setores de "fora da porteira" da fazenda (63\%). Neste mesmo ano, as exportaçes brasileiras tiveram uma contribuiçăo de cerca de $40 \%$ ariundas destes complexos (FLORES et. alii, 1991).

Com a industrializaçăo da economia brasileira, a partir dos diversos planos de desenvolvimento elaborados pelo governo no final das décadas de 50,60 e início da década de 70, era natural e necessário que a agricultura tambem se modernizasse. Mas essa modernizaçăo nåo foi homogênea. Algumas culturas passaram por profundas mudanças na

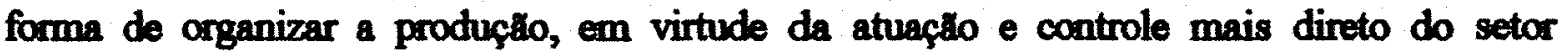
industrial sobre a produçăo agricola. Este maior controle traduziu-se, em última analise, na maior integraçăo agricultura-indústria e objetivou, sobretudo, integrar o setor agricola a dinamica de acumulaçăo do capital urbano-industrial. Por outro lado, algumas culturas næo sofreram mudanças na sua forma de organizaçălo, em virtude principalmente do desenvolvimento da produgito rural, das especificidades regionais, da natureza do processamento agroindústrial e das politicas estatais (HESPANHOL, 1992). O grau de estreitamento entro o setor agricola e a produçăo agroindustrial depende do produto analisado. Quando o produto possui, além da incústria processadora, outros mercados alternativos , o poder de barganha do procutor é maior, mas quando não existe tal mercado alternativo (ex. cana-de-açucar, fumo, algodalo), o poder de barganha do produtor é bem menor (FEIJÓ et alii, 1990).

Essa modernizaç̆o da agricultura foi provocada pelas mudanças tecnologicas que elevaram a procutividade da terre e do trabalho, o que resultou em mudancas nas relaçoes de trabalho e no quadro social da agricultura. A concentraçto da terra e da renda e a 
exchusåo de grande número de pequenos e médios produtores foram o corolário natural dessa modernizaç̆o apoiada por uma efetiva intervençắo do Estado (MARTINS, 1986).

Quando observamos o sucesso de alguns complexos agroindustriais na economia brasileira, como é o caso da laranja, tomate, algadăo e aves, devemos considerar que tal sucesso não se deve apenas ds forças de mercado, pois a açăo do Estado foi fundamental para a evoluçăo dessas atividades e das respectivas inđústrias de processamento, seja através da politica de crédito rural, do desenvolvimento de novas variedades (caso da laranja e sobretudo do algodáo), do desenvolvimento de linhagens de aves com melhor conversto alimentar, da definiçăo de preços minimos de alguns produtos, ou da implementaçăo de politicas que favoreceram a exportaçăo de produtos elaborados (HESPANHOL, 1992). Com respeito à cultura do maracuje, este ponto é muito importante, pois segundo os técnicos da área de processamento (citado por SATO et alii 1992), o alto custo da matéria-prima está inviabilizando o processamento para exportaçåo. Uma caixa de maracujá custa ao produtor USS 2,50 e săo necessárias 700 caixas para produzir uma tonelada de suco com 50 graus Brix que, por sua vez, é cotada no mercado externo a USS $1.500,00$ - USS 2.000,00/t FOB. Para esses mesmos técnicos, a única possibilidade de diminuiçăo do custo da matéria-prima está no aumento da produtividade do maracuja que no momento se encontra muito baixa (em torno de 2,0 a 2,5 caixas por planta).

\section{3) Agroindustria e desenvolvimento}

Esta secta discute alguns trabalhos que investigam o efeito da agroincústria sobre o desenvolvimento regional, principalmente sobre o nivel de emprego e renda.

DOEKSEN e SCHREINER(1972), elaboraram um modelo de simulaçăo, utilizando o sistema basico de LEONTIEF de insumo-produto para o Estado de Oklahoma, 1970 , com o objetivo de verificar o impacto da instalaģăo de uma intústria processadora de produtos agricolas no nivel de emprego e renda em um Estado cuja economia era voltada 
para a produção de produtos agricolas. Os resultados do estudo mostraram que o setor de processamento agricola era o setor que mais criava emprego diretos e indiretos, além de possuir os maiores multiplicadores de emprego, só sendo ultrapassado pelo setor de petróleo (Tabela 8). Cada multiplicador indica a mudança de empregos diretos e indiretos gerados $\mathbf{n a}$ economia de Oklahoma com a mudança de uma unidade de oferta de emprego em cada setor. Quanto maior săo esses multiplicadores, maiores săo as relaçờes entre o setor especifico e os restante dos setores da economia. A interpretação desse multiplicador é feita da seguinte maneira: tomando-se o setor de processamento agricola como exemplo, cujo valor do multiplicador de 6,29 , cada homem-ano empregado diretamente neste setor proporciona na demanda final, 5,29 homens-ano adicionais para a economia. Ao analisar o custo de investimento para a formaçăo de 100 empregos diretos e indiretos, oberva-se que o setor de processamento agricola é o setor que requer uma menor quantidade de investimento tanto no curto como no longo prazo (Tabela 9).

YOUNG (1993) estudou a oferta de emprego e o desenvolvimento agroindustrial no México, na regiăo conhecida como El Bajio. Nessa regiåo foram instaladas grandes unidades agroindustriais, principalmente empresas norte-americanas, que provocaram uma modificaçăo do uso da terra na regił̌o, ccorrendo um aumento acentuado no plantio de sorgo e uma diminuiçăo na oferta de empregos rurais, pois a mudança na tecnologia de produçăo agricola proporcionou um maior mecanizaçăo, diminuindo a necessidade de måo-de-obra e provocando um aumento na sua sazonalidade. Por outro lado, hourve um aumento acentuado da produtividade, principalmente devido à utilizaçăo de irrigaçăo. $O$ autor verificou que na época de pico, a oferta de emprego nas unidades processadoras de frutas e vegetais atingia o nivel de 11000 empregos, sendo 3/4 desses 
Tabela 8. Investimento de US\$ 1 milhäo na melhoria da capacidade industrial em Oklahoma em 1970 e seu impacto no nivel de emprego de curto, médio e longo prazos e seus multiplicadores.

\begin{tabular}{|c|c|c|c|c|c|c|c|c|c|c|c|c|}
\hline \multirow[t]{2}{*}{ Investimento } & \multirow{2}{*}{$\begin{array}{l}\text { Empre- } \\
\text { go } \\
\text { direto }\end{array}$} & \multirow{2}{*}{$\begin{array}{l}\text { Empre- } \\
\text { go } \\
\text { direto e } \\
\text { indire- } \\
\text { to }\end{array}$} & \multirow{2}{*}{$\begin{array}{l}\text { Efeito } \\
\text { na } \\
\text { forma- } \\
\text { căo de } \\
\text { capital }\end{array}$} & \multirow{2}{*}{$\begin{array}{l}\text { Efeito } \\
\text { total no } \\
\text { curto } \\
\text { prazo }\end{array}$} & \multirow{2}{*}{$\begin{array}{l}\text { Efeito } \\
\text { total no } \\
\text { ge- } \\
\text { gundo } \\
\text { ano }\end{array}$} & \multirow{2}{*}{$\begin{array}{l}\text { Efeito } \\
\text { total no } \\
\text { ter- } \\
\text { ceiro } \\
\text { ano }\end{array}$} & \multirow{2}{*}{$\begin{array}{l}\text { Efeito } \\
\text { total no } \\
\text { longo } \\
\text { prazo }\end{array}$} & \multirow{2}{*}{$\begin{array}{l}\text { Oferta } \\
\text { de } \\
\text { empre- } \\
\text { go no } \\
\text { curto } \\
\text { prazo }\end{array}$} & \multicolumn{4}{|c|}{ Nivel Total de emprego } \\
\hline & & & & & & & & & $\begin{array}{l}\text { No curto } \\
\text { prazo } \\
(9)^{b}\end{array}$ & $\begin{array}{l}\text { No } 2^{\circ} \\
\text { ano } \\
(10)^{c}\end{array}$ & $\begin{array}{c}\text { No } 3^{0} \\
\text { ano } \\
(11)^{c}\end{array}$ & $\begin{array}{c}\text { No longo } \\
\text { prazo } \\
(12)^{d}\end{array}$ \\
\hline & \multicolumn{7}{|c|}{ Nivel de emprego em equivalentes homem-ano } & \multicolumn{5}{|c|}{ Multiplicador } \\
\hline Pecuéria & 59 & 140 & 68 & 208 & 332 & 258 & 121 & 2,37 & 3,52 & 5,63 & 4,37 & 2,05 \\
\hline Lavoura & 111 & 128 & 75 & 213 & 301 & 228 & 80 & 1,24 & 1,92 & 2,71 & 2,05 & 0,72 \\
\hline Processamento agricola & 78 & 491 & 65 & 556 & 982 & 901 & 488 & 6,29 & 7,13 & 12,59 & 11,55 & 6,25 \\
\hline Petroleo & 12 & 87 & 64 & 151 & 325 & 255 & 75 & 7,25 & 12,58 & 27,08 & 21,25 & 6,25 \\
\hline Maquinas & 76 & 154 & 67 & 221 & 353 & 296 & 196 & 2,02 & 2,91 & 4,64 & 3,89 & 2,58 \\
\hline Outras industrias & 82 & 153 & 68 & 221 & 356 & 303 & 257 & 1,87 & 2,60 & 4,34 & 3,69 & 3,13 \\
\hline Minerac:10 & 32 & 68 & 78 & 146 & 252 & 181 & 67 & 2,12 & 4,56 & 7,87 & 5,66 & 2,10 \\
\hline Trangp. comucafð̄es etc. & 24 & 37 & 59 & 96 & 177 & 120 & 40 & 1,54 & 4,00 & 7,37 & 5,00 & 1,66 \\
\hline Financas e segaros & 80 & 122 & 67 & 189 & 282 & 219 & 127 & 1,52 & 2,36 & 3,53 & 2,74 & 1,59 \\
\hline Serviços & 221 & 288 & 64 & 352 & 486 & 442 & 359 & 1,30 & 1,59 & 2,19 & 2,00 & 1,62 \\
\hline Atacadista e varejo & 226 & 291 & 71 & 362 & 498 & 444 & 353 & 1,29 & 1,60 & 2,20 & 1,96 & 1,56 \\
\hline construgtio & 152 & 359 & 62 & 421 & 662 & 610 & 391 & 2,36 & 2,76 & 4,36 & 4,01 & 2,57 \\
\hline
\end{tabular}

\footnotetext{
IA coluna (3) representa o efeito da formaça de capital ou seja, indica a quantidade de equivalentes homem-ano requerida para produzir US\$ 1 milhăo para cada setor

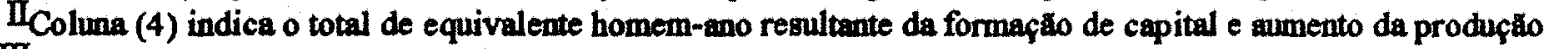

IIIs colunas (5), (6), (10), (11), săo os efeitos nos prazos intermediários

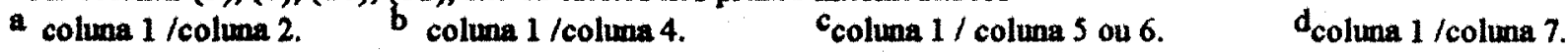

Fonte: Doeksen, G. A e Schreiner D. F., 1972. p.516
} 
empregos exercidos por mulheres. Em contraste, as grandes unidades alimenticias de cereais empregavam somente ao redor de 200 empregados.

Tabels 9 - Custo de investimento pars a produclo de 100 empregos no curto, médio e longo prazo em Oklahoma, 1970.

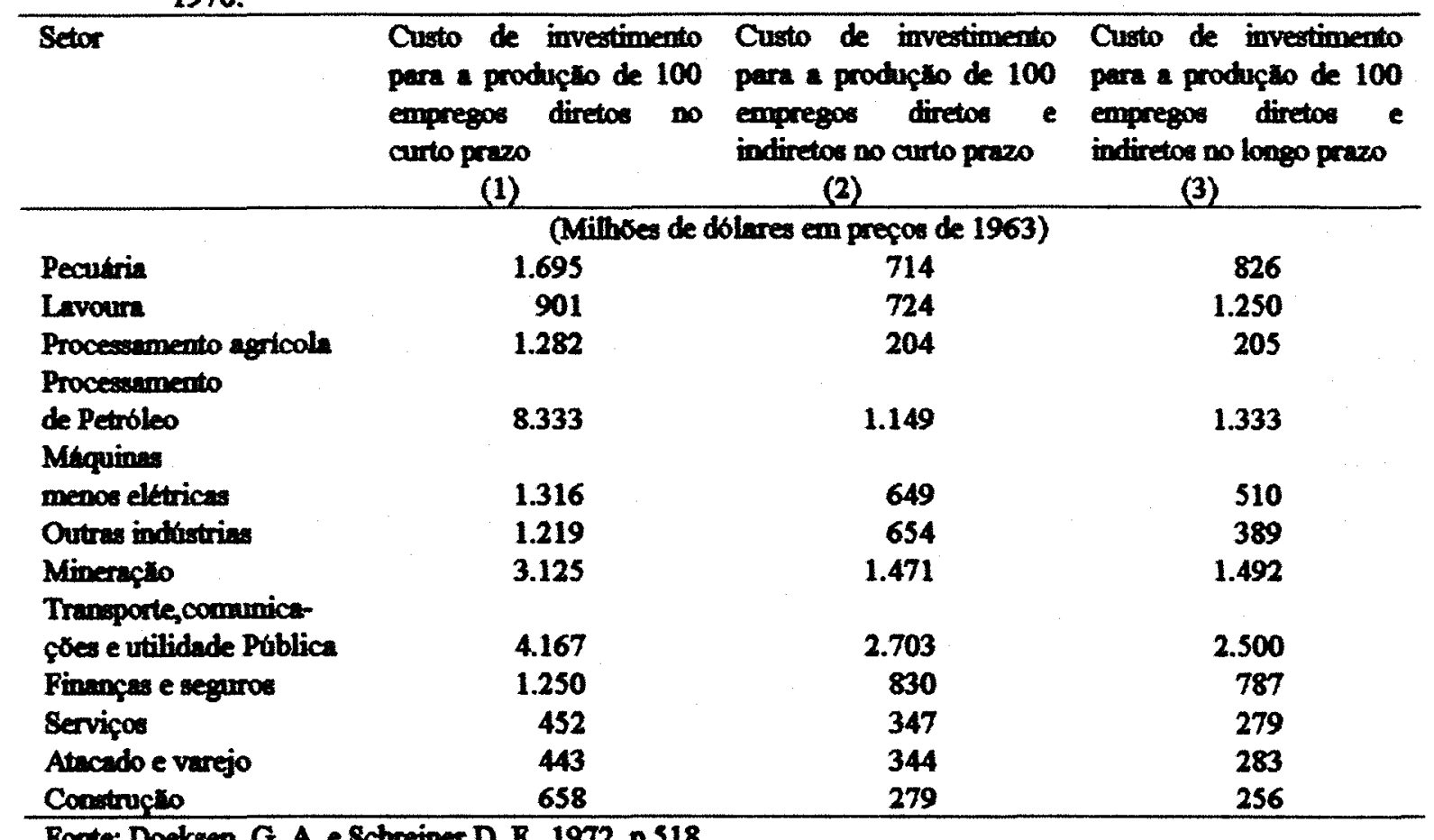

Este trabalho analisou somente o impacto no emprego direto na agricultura e concluiu que seu efeito não d muito grande, mas deve ser levado em conta que tipos de produtos agricolas săo processados, pois existem atividades como o sorgo, trigo, cevada, etc, que além de serem totalmente mecanizadas, possuem uma forte economia de escala. Um ponto positivo notado pelo autor foi o efeito "spill-over" ocorrido devido ao desenvolvimento agroindustrial na regiăo, isto e: as novas técnicas introduzidas para a produçăo das matériasprimas requeridas, foram introduzidas nas lavouras tradicionais da regiâo.

AHAMMED e HERT (1984), utilizando o método de matriz de contabilidade social, verificaram o efeito direto e indireto da introducta de tecnologia moderna na produçăo de arroz, especialmente a mecanizaçă, no nivel de emprego nas Filipinas. Verificaram que a maioria dos autores enfatiza apenas o efeito direto na introduçăo dessa 
tecnologia, que é a diminuiçăo da oferta de emprego no setor agricola. Os efeitos indiretos, segundo os autores, se refletem nos setores não agricolas (indústrias à montante e à jusante). O resultado do trabalho mostra que o aumento do nivel de emprego devido a introduçăo de novas tecnologias, depende principalmente do seu efeito de encadeamento, isto é, o aumento no nivel de mecanizaçăo, aumenta o efeito na demanda por equipamentos agricolas e consequentemente expande o nivel de emprego na industria. Estes resultados indicam a importância em se reconhecer a interdependência entre os setores e a capacidade individual de cada setor de reagir ao aumento da demanda devido ao crescimento da agricultura.

DE PAULA et alii (1994) utilizaram a matriz insumo-produto elaborada pela FIBGE para 1980, como a principal fonte de dados para determinar o custo dos recursos domésticos e a competitividade da agricultura brasileira. Um dos resultados gerados por esta pesquisa foi o número de empregos gerados direta e indiretamente por produtos e por atividades (Tabela 10), onde é possivel verificar as relaçסes intersetoriais entre a agricultura e a indústria.

MARTIN (1993), ao propor açőes locais, que visem recuperar a atividade agropecuária, fala da necessidade de se buscar parcerias entre os diferentes setores municipais e estaduais, visando somar forças na implantaçăo de projetos locais, comprovadamente viáveis (atraves de um estudo de viabilidade econômica) e localizados. Esses projetos teriam como objetivo principal uma maior diversificaçăo da agropecuária atraves do fomento de pequenas e médias agrointústrias bem como sua integraçăo a sistemas mais complexos. 
Tabela 10 - Coeficientes de geraça de empregos diretos e indiretos, por atividade, para cada milhto de cruzeiros investidos

\begin{tabular}{|c|c|}
\hline Atividades & Empregos/US\$ $19,000.00$ investidos \\
\hline Café em coco & 9,7716 \\
\hline Culturas permanentes e reflorestamento & 9,7716 \\
\hline Raçoes e forragens para animais & 4,7317 \\
\hline Industria de trator & 1,5882 \\
\hline Maquinas, Equipamentos e Instalsçres de uso industrial & 1,8162 \\
\hline Fabricaçuo de Adubos, Fertilizantes e Corretivos do solo & 0,6368 \\
\hline Café em Grto, torrado, moldo ou solúvel & 8,2503 \\
\hline Arros beneficiado & 8,1297 \\
\hline Parinhs, amido e feculs de trigo & 9,6627 \\
\hline Sucos e Conservas de frutas e legumes & 3,8888 \\
\hline
\end{tabular}

Fonte: Relatório de Pesquisas, outubro de 1994. IPEA. US\$1,00 - Cr\$ 52,699 ano de 1980

\section{4) Estudos de Projetos Agroindustriais}

Nesta parte do trabalho serăo analisados alguns projetos agroindústriais com relaçåo a sua taxa intema de retomo (TIR), ponto de equilibrio (P.E. percentagem da capacidade utilizada da unidade de processamento onde se verifica a igualdade entre receita total e custo total), capacidade operacional e as variáveis mais sensiveis dos projetos.

Quando se realiza uma andlise financeira de um projeto de investimento é preciso incluir no fluxo de caixa desse projeto a depreciaçăo, juros sob financiamento e amortizaçăo. Esse tipo de trabalho foi realizado por SENA (1988). No caso de análise econômica de um projeto, esses itens nåo devem ser incluidos no fluxo de caixa.

LETTE et alii (1982) realizaram um estudo técnico-econômico para implantaçåo de uma unidade industrial para produçăo de cebola e pimenta desidratadas, com capacidade de processar $301 \mathrm{~kg} / \mathrm{h}$ de pimenta com umidade de $80 \%$ e $422 \mathrm{~kg} / \mathrm{h}$ de cebola "in 
natura". O P.E. para o processamento da cebola e da pimenta foram respectivamente de $62,22 \%$ e $63,26 \%$. A TIR encontrada foi de $21,89 \%$ a.a., valor esse que foi comparado com a taxa de juros oferecida pelo Banco Nacional de Desenvolvimento Econômico e Social (BNDES) que variava de 3 a $9 \%$. A análise de sensibilidade da TIR mostrou que a mesma foi mais sensível a variaçðes da matéria-prima (M-P), mão-de-obra mais encargos e receita total.

ALMEIDA et alii (1983) estudaram a viabilidade económica de uma unidade industrial de batata pré-frita e hortaliças (cenoura e morango) congeladas. O processamento da matéria-prima para o caso básico foi planejado da seguinte maneira: a batata é processada de outubro a maio, a cenoura de maio a junho e o morango de julho a setembro. Foram utilizadas as seguintes capacidades operacionais para a unidade industrial: 5880 $\mathrm{kg} / \mathrm{h}$ de batata pré-frita, $3000 \mathrm{~kg} / \mathrm{h}$ de cenoura e $2400 \mathrm{~kg} / \mathrm{h}$ de morango. Foram encontrados os valores de $33 \%, 46 \%$ e $33 \%$ para o P.E. da batata, cenoura e morango respectivamente. A TIR calculada no projeto foi 46,7\%, comparada com a taxa real de juros de $8 \%$ a.a., utilizada pelo BNDES para financiamento de indústrias alimenticias. Quando realizada a análise de sensibilidade, verificou-se que as variáveis matéria-prima, mão-de-obra, receita e capacidade utilizada da unidade industrial, foram as que mais afetaram a TIR.

CANTO et alii (1987) estudaram o processamento de frutas secas (caqui, uva ameixa e banana). A uva, ameixa, banana e caqui såo processados respectivamente nos seguintes meses: dezembro a fevereiro, setembro a novembro, abril e julho, e fevereiro, março, maio, junho. A capacidade de processamento foi de: $334 \mathrm{~kg} / \mathrm{h}$ de caqui, $1000 \mathrm{~kg} / \mathrm{h}$ de ameixa, $1000 \mathrm{~kg} / \mathrm{h}$ de uva e $1000 \mathrm{~kg} / \mathrm{h}$ de banana. A TIR calculada para o projeto foi de 46,52\%. Comparada com as taxas de juros cobradas pelos bancos oficiais de investimentos para projetos industriais na área de alimentos que eram de 6 a $8 \%$ a.a., foi considerado um investimento economicamente viável. Os autores verificaram que a TIR se mostrou mais sensivel a variações nos valores dos produtos finais (receitas), da matéria-prima, da măo-deobra e da energia elétrica, em ordem decrescente. 
ALMEIDA (1981) estudou a viabilidade económica da implantação de unidades produtoras de farinha de milho integral e desengordurada para utilizaçåo com trigo utilizando diversas capacidades operacionais. As taxas internas de retorno para diferentes capacidades operacionais foram as seguintes: a) para a fábrica de $100 \mathrm{t} / \mathrm{dia}$ a TIR foi de $15,31 \%$; b) para $200 \mathrm{t} /$ dia a TIR foi de $33,67 \%$; c) para $500 \mathrm{t} / \mathrm{dia}$ a TIR foi de $47,52 \%$ e d) para 1000 Vdia a TIR foi de $59,19 \%$. Essas taxas foram comparadas com a taxa real de juros cujo valor era de $8 \%$. As variáveis que mais afetaram a TIR na análise de sensibilidade foram a matéria-prima, a mão-de-obra, combustiveis mais energia elétrica, embalagem e receita.

SENA (1988) estudou economia de escala no processamento de frutas e hortaliças (tomate, manga e goiaba) para a produção de polpas, massas, néctar e goiabada nas seguintes capacidades operacionais: $500 \mathrm{~kg} / \mathrm{h}, 1000 \mathrm{~kg} / \mathrm{h}, 2500 \mathrm{~kg} / \mathrm{h}$ e $5000 \mathrm{~kg} / \mathrm{h}$. As suas respectivas TIRs foram: $7 \%, 23 \%, 33 \%$ e $50 \%$. Essas TIRs foram comparadas com o custo de oportunidade de mercado, 6\%. O P.E. para as respectivas capacidades operacionais foram: $30,79 \%, 16,70 \%, 11,63 \%$ e $7,09 \%$. Os resultados do estudo mostraram que a TIR foi mais sensivel a variaçóes das receitas e da matéria-prima.

Um dos objetivos desta revisåo foi tentar mostrar o papel da agroindústria no processo de desenvolvimento de uma regiăo. Neste sentido é consenso entre os autores revistos que atualmente é necessário analisar a agricultura de uma forma intersetorial, interdependente, pois no estágio em que se encontra a economin brasileira, é visivel a ausência de autonomia de seus setores, além do que esse tipo de análise facilita a visualizaçăo da transmissåo do progresso técnico.

Foi destacado o papel importante tanto da indústria montante como a jusante, no papel de difusão tecnológica para o setor agricola. Além disso, a maioria dos autores concorda que a agroinctustria e fator importante no dinamismo de regióes agricolas, principalmente como elemento gerador de emprego direto e indireto, e de renda. 
A maioria dos estudos revistos acima, que tratou da viabilidade econômica de diferentes agroindústrias, não teve entretanto, preocupaçăo com o impacto das mesmas no nível de empregos locais. Por outro lado, os trabalhos revisados que analisaram o impacto da instalação de uma agroindústria no nivel de emprego, utilizaram a matriz insumo-produto ou uma matriz de contabilidade social, pressupondo logicamente que tal atividade era lucrativa. Esse trabalho tem as duas preocupações, ou seja, verificar a viabilidade econômica de uma indústria de extração de sucos de frutas em Vera Cruz, assim como seu impacto no nivel de emprego e renda do município. 


\section{3) METODOLOGIA}

\section{1) Introdugxio}

Este capitulo descreve a metodologia utilizada no estudo de viabilidade econômica de uma indústria de suco de maracujá e de abacaxi no município de Vera Cruz, no Estado de Såo Paulo. Em primeiro lugar, indica-se os critérios usados na determinaçăo da capacidade minima da unidade produtora de suco. Em seguida, discute-se o método selecionado para a avaliação econômica da referida unidade produtora. Finalmente, são apresentadas as variáveis cujos valores săo alterados para se conhecer a sensibilidade do resultado econômico d̀s variações das mesmas.

\section{2) Capacidade minima da unidade produtora}

A capacidade minima da unidade produtora foi determinada juntamente pelo setor de Engenharia e Pesquisa do Instituto de Tecnologia de Alimentos (ITAL), com base nos seguintes critérios:

a) disponibilidade de equipamentos no mercado e

b) disponibilidade de matéria-prima no municipio.

\section{3) Método de avaliaç̧̃o econômica}

\subsection{1) Introduçüo}

Num estudo de viabilidade econômica de uma indústria, a determinaçăo da capacidade apropriada de instalaçăo é indispensável. Esta está em função da capacidade de 
fornecimento da matéria-prima, da capacidade de investimento e do nivel de demanda. Após definir a capacidade de instalaçåo da indústria, é preciso detalhar a estrutura de custo do empreendimento e a estimativa da receita futura, para se poder elaborar um fluxo de caixa (Tabela 11) e a partir dai calcular a TIR (taxa interna de retorno) do investimento. Após o cálculo da TTR, faz-se uma análise de sensibilidade para verificar quais são as variáveis independentes que mais influenciam seu valor e consequentemente a viabilidade económica.

\subsection{2) Estrutura do Fluxo de Caira}

O horizonte econômico do projeto de instalaçăo da unidade de processamento de suco foi fixado em 20 anos, considerando-se que os preços cotados no periodo 0 (zero) (1995), permanecem inalterados. Pressupze-se que a taxa de inflaçăo influencia igualmente os preços dos insumos e dos produtos do projeto (NORONHA, 1987).

De acordo com a tecnologia e o nivel de produçăo, foi estabelecido um programa de investimento, receitas e custos operacionais para cada ano da vida do projeto, sendo que o fluxo de caixa liquido para cada ano foi obtido por:

$$
\begin{aligned}
& a_{j}=R_{j}-I_{j}-C_{j} \quad(j=1, \ldots, 20) \\
& \text { onde : } \\
& a_{j}=\text { fluxo de caixa liquido no ano } j ; \\
& I_{j}=\text { investimento no ano } j ; \\
& R_{j}=\text { receita bruta no ano } j ; \\
& C_{j}=\text { custo operacional no ano } j ;
\end{aligned}
$$

O fluxo de caixa do projeto formado pelos investimentos (edificaçoes, equipamentos, velculos, paletes, outros), capital de giro, receita bruta e pelo custo operacional (mão-de-obra fixa e variável, matéria-prima, embalagem, eletricidade, combustivel e outros). Este último é definido como o custo total de proctuçåo menos a 
depreciação, que está incluida no custo fixo, os juros sobre o investimento fixo e o imposto de renda. Så justificadas as exclusões desses itens do custo operacional da seguinte maneira: a) a depreciação é excluida para evitar dupla contagem uma vez que se considera o investimento fixo de bem de capital, no fluxo de caixa; b) os juros sobre o investimento, são retirados para que seja possivel a comparaçăo da TIR com o custo do capital no mercado e também pelo fato de se pretender medir a lucratividade do capital investido, independente de como ele é financiado; c) o imposto de renda não é considerado pois se constitui mais numa especie de distribuição de lucros do que num verdadeiro custo operacional e no caso do estudo de viabilidade econômica năo interessa a quem os lucros são distribuidos (ALMEIDA, 1981).

Segundo a UNIDO (Organização para o Desenvolvimento Industrial da Nações Unidas), o custo total de investimentos é formado pelos montantes dos gastos de pré-produção, investimentos fixos e do capital de giro líquido. $O$ capital de giro inicial indica os meios financeiros necessários para operar o projeto de acordo com seu programa de produção. E definido como o ativo circulante menos o passivo circulante. A necessidade de capital de giro liquido varia de acordo com as diferentes etapas de produçăo. Seu cálculo neste estágio de viabilidade é de especial importância, já que ele força os promotores do projeto a pensarem sobre os fundos necessários para financiar a operaçăo do projeto ao invés dos fundos investidos, como os custos de capital de pré-produçăo e investimentos fixos (ativo fixo). NORONHA (1987) mostra alguns exemplos de fluxo de caixa onde discute a necessidade de inclusåo do capital de giro no fluxo de caixa, o que irá provocar uma diminuiçăo da TIR. Nesses mesmos exemplos o autor recomenda a nåo inclusão no fluxo de caixa da depreciaçlo e dos fluxos financeiros, isto $e$, as entradas de dinheiro externo sob a forma de financiamento e os encargos ou saidas correspondentes. A inclusăo deste item no fluxo de caixa tenderia a aumentar a TIR.

No perfodo "0", o fluxo de caixa é negativo já que a receita total é igual a zero e entăo o valor do fluxo de caixa será igual ao valor do investimento inicial com sinal 
negativo. Nos periodos subsequentes, o fluxo de caixa poderá ser positivo ou negativo, dependendo do valor da receita total, do custo operacional e do investimento. A Tabela 11 mostra como săo calculados os fluxos de caixa, a partir dos quais é calculada a TIR do projeto básico.

Para o cálculo do valor residual do projeto no fluxo de caixa ao final de sua duração (20 anos), considerou-se a vida útil dos prédios e instalações em 20 anos. No vigésimo ano, $50 \%$ do valor investido na construçăo civil são considerados como valor residual no final da vida útil do projeto. Para equipamentos, a vida útil foi estipulada em 10 anos. Portanto, novos investimentos nesse item såo efetuados no $8^{\circ}, 9^{\circ}$ e $10^{\circ}$ anos. $O$ valor dos novos investimentos e o valor residual corresponderåo respectivamente a $20 \%$ e a $40 \%$ do investimento inicial. Quanto ao item referente aos veiculos, a vida útil foi estipulada em 5 anos, sendo novos investimentos realizados, respectivamente nos $50,10^{\circ}$ e $15^{\circ}$ anos do projeto, correspondendo a $60 \%$ do investimento inicial; seu valor residual corresponderá a $40 \%$ do investimento inicial. No item paletes, havera uma reposiçăo anual de $20 \%$ do investimento inicial e seu valor residual corresponderá a $80 \%$ do valor inicial. No item outros investimentos seu valor residual correspondera a $28 \%$ do investimento inicial. O valor residual do capital de giro será o montante necessário para iniciar o negócio.

\subsection{3) A Taxa Intema de Retomo}

Os métodos de avaliaçáo económica de projetos podem ser divididos em métodos que năo consideram as transformações de valor do dinheiro no tempo, e métodos que consideram essas transformaçōes. Esses primeiros métodos, mais imprecisos, são representados pelo perfodo de recuperaçăo de capital ( ou "payback period") e pelo retorno 
Tabola 11. Emtruturn do Fhro do Caira Proposto.

\begin{tabular}{|c|c|c|c|c|c|c|c|c|c|c|c|c|c|}
\hline \multirow[t]{2}{*}{ Itom } & \multirow[t]{2}{*}{ Sub-itom } & \multirow[t]{2}{*}{ Siglas } & \multicolumn{11}{|c|}{ Ano } \\
\hline & & & 0 & 1 & 2 & 3 & 4 & 5 & 6 & 7 & 8 & 9 & 10 \\
\hline & Edificapōes & Ed & -Ed & & & & & & & & & & \\
\hline Investimonto & Equipamentos & $\mathbf{E q}$ & & & & & & & & & $.20 \% \mathrm{Eq}$ & $-20 \% \mathrm{Eq}$ & $-20 \% \mathrm{Eq}$ \\
\hline \multirow[t]{3}{*}{ Fixo } & Voículo: & $\mathbf{V}$ & & & & & & $-60 \%$ & & & & & \\
\hline & Paletes & $\mathbf{p}$ & $-20 \% a$ & $-20 \% \mathrm{p}$ & $-20 \% \mathrm{P}$ & $-20 \% \mathrm{aP}$ & $-20 \% \mathrm{P}$ & $-20 \% \mathrm{P}$ & $-20 \% \mathrm{P}$ & $-20 \% \mathrm{P}$ & $-20 \% \mathrm{P}$ & $-20 \% \mathrm{P}$ & $-20 \% \mathrm{P}$ \\
\hline & Outros & 0 & & & & & & & & & & & \\
\hline Capial Giro & & $\mathrm{Cg}_{\mathrm{g}}$ & & & & & & $-60 \% \mathrm{~V}$ & & & & & $-60 \% \mathrm{~V}$ \\
\hline \multirow[t]{4}{*}{ Sub-Total 1} & & $\mathbf{I}$ & $-x_{0}$ & $-I_{1}$ & $-I_{2}$ & $-I_{3}$ & $-x_{4}$ & Is & $-I_{6}$ & $-I_{7}$ & $\cdot \mathrm{I}_{8}$ & $-I_{9}$ & $-I_{10}$ \\
\hline & MOFV+Enc 2 & $\mathrm{Cm}$ & $\cdot \mathrm{Cm}$ & $-\mathrm{Cm}$ & $\cdot \mathrm{Cm}$ & $-\mathrm{Cm}$ & $-\mathrm{Cm}$ & $\cdot \mathrm{Cm}$ & $-\mathrm{Cm}$ & $-\mathrm{Cm}$ & $-\mathrm{Cm}$ & $-\mathrm{Cm}$ & $-\mathrm{Cm}$ \\
\hline & Matória-Prime & Cmp & . Cmp & -Cmp & .Canp & -Cmp & $-\operatorname{Cmp}$ & -Cmp & $-\operatorname{Cmp}$ & Cmp & - Cmp & -Cmp & . Cmp \\
\hline & Embalagem & $\mathrm{Co}$ &. $\mathrm{Ce}$ &. $\mathrm{Ce}$ & -Ce & -Co & $-\mathrm{Ce}$ &. $\mathrm{Ce}$ & $-\mathrm{Co}$ & -Co & $-\mathrm{Ce}$ & $-\mathrm{Co}$ & $-\mathrm{Co}$ \\
\hline \multirow{3}{*}{$\begin{array}{l}\text { Curto } \\
\text { Operncional }\end{array}$} & Elomicidade main & Cec & - Cec & -Cec & $-\operatorname{Cec}$ & $-\operatorname{Cec}$ & $-\mathrm{Cec}$ & $\cdot \mathrm{Cec}$ & - Cec & -Cec & $\cdot \operatorname{Cec}$ & - Cec &. $\operatorname{Cec}$ \\
\hline & comburtivel & & & & & & & & & & & & \\
\hline & Outros & 0 & .0 & .0 & .0 & .0 & -0 & .0 & -0 & -0 & .0 & -0 & .0 \\
\hline Sub-Total ${ }^{3}$ & & C & $\cdot c_{n}$ & $\cdot \mathrm{C}_{1}$ & $\cdot C_{2}$ & $-C_{3}$ & $\cdot c_{4}$ &.$_{s}$ & $-C_{K}$ & $\cdot C_{7}$ & $\cdot \mathrm{C}_{\mathrm{R}}$ & $-C_{9}$ & $-C_{10}$ \\
\hline Receits Total & & $\mathbf{R}$ & $+\mathbf{R}$ & $+\mathbf{R}$ & $+\mathbf{R}$ & $+\mathbf{R}$ & $+\mathbf{R}$ & $+\mathbf{R}$ & $+\mathbf{R}$ & $+\mathbf{R}$ & $+\mathbf{R}$ & $+\mathbf{R}$ & $+\mathbf{R}$ \\
\hline Furo de Caime 4 & & $\mathbf{a}$ & $+1-2 n$ & $+f-a_{1}$ & $+1-8$ & $+/ \cdot a_{3}$ & $+/-2 x$ & $+/-25$ & $+/ .96$ & $+1-27$ & +1.28 & $+1-29$ & +1.910 \\
\hline
\end{tabular}




\begin{tabular}{|c|c|c|c|c|c|c|c|c|c|c|c|c|}
\hline \multirow[t]{2}{*}{ Item } & \multirow[t]{2}{*}{ Sub-item } & \multirow[t]{2}{*}{ Siglas } & \multicolumn{9}{|c|}{ Ano } & \multirow{2}{*}{$\begin{array}{l}\text { Valor } \\
\text { Residual } \\
\end{array}$} \\
\hline & & & 11 & 12 & 13 & 14 & 15 & 16 & 17 & 18 & 19 & \\
\hline & Edificaçoea & Ed & & & & & & & & & & $50 \% \mathrm{Ed}$ \\
\hline Investimento & Equipamentos & $\mathrm{Eq}$ & & & & & & & & & & $40 \% \mathrm{Eq}$ \\
\hline \multirow[t]{3}{*}{ Fixo } & Veículos & V & & & & & $-60 \% \mathrm{~V}$ & & & & & $40 \% \mathrm{~V}$ \\
\hline & Paletes & $\mathbf{P}$ & $-20 \% \mathrm{P}$ & $-20 \% \mathrm{P}$ & $-20 \% \mathrm{P}$ & $-20 \% \mathrm{P}$ & $-20 \% \mathrm{P}$ & $-20 \% \mathrm{P}$ & $-20 \% \mathrm{P}$ & $-20 \% \mathrm{P}$ & $-20 \% \mathrm{P}$ & $80 \% \mathrm{P}$ \\
\hline & Outros & $\mathrm{o}$ & & & & & & & & & & $28 \% O$ \\
\hline Capital Giro & & $\mathrm{Cg}$ & & & & & & & & & & $\mathrm{Cg}$ \\
\hline \multirow[t]{3}{*}{ Sub-Total 1} & & I & $-I_{11}$ & $-I_{12}$ & $-I_{13}$ & $-I_{14}$ & $-I_{1.5}$ & -116 & $-I_{17}$ & $-I_{18}$ & $-I_{19}$ & $-I_{20}$ \\
\hline & MOFV+Enc ${ }^{2}$ & $\mathrm{Cm}$ & $-\mathrm{Cm}$ & $-\mathrm{Cm}$ & $-\mathrm{Cm}$ & $-\mathrm{Cm}$ & $-\mathrm{Cm}$ & $-\mathrm{Cm}$ & $-C m$ & $-\mathrm{Cm}$ & $-\mathrm{Cm}$ & $-\mathrm{Cm}$ \\
\hline & Matéria-Prima & Cmp & - Cmp & $-\operatorname{Cmp}$ & $-C m p$ & $-C m p$ & $-\operatorname{Cmp}$ & $-C m p$ & - Cmp & - Cmp & -Cmp & - Cmp \\
\hline Custo & Embalagem & $\mathrm{Ce}$ & $-\mathrm{Ce}$ & $-\mathrm{Ce}$ & $-\mathrm{Ce}$ & $-\mathrm{Ce}$ & $-\mathrm{Ce}$ & $-\mathrm{Ce}$ & $-\mathrm{Ce}$ & $-\mathrm{Ce}$ & $-\mathrm{Ce}$ & $-\mathrm{Ce}$ \\
\hline \multirow[t]{3}{*}{ Operacional } & Eletricidade mais & Cec & - Cec & $-\mathrm{Cec}$ & $-\operatorname{Cec}$ & $-\mathrm{Cec}$ & $-\mathrm{Cec}$ & $-\operatorname{Cec}$ & $-\mathrm{Cec}$ & $-\mathrm{Cec}$ & - Cec & $-\mathrm{Cec}$ \\
\hline & combustivel & & & & & & & & & & & \\
\hline & Outros & 0 & .0 & -0 & -0 & -0 & -0 & -0 & $-\mathrm{O}$ & -0 & -0 & -0 \\
\hline \multicolumn{2}{|l|}{ Sub-Total 3} & $\mathrm{C}$ & $-C_{11}$ & $-C_{12}$ & $-C_{13}$ & $-C_{14}$ & $-C_{15}$ & $-C_{16}$ & $-C_{17}$ & $-C_{18}$ & $-C_{19}$ & $-C_{20}$ \\
\hline \multicolumn{2}{|l|}{ Receita Total } & $\mathbf{R}$ & $+R$ & $+R$ & $+\mathbf{R}$ & $+\mathbf{R}$ & $+\mathbf{R}$ & $+\mathbf{R}$ & $+\mathbf{R}$ & $+\mathbf{R}$ & $+\mathrm{R}$ & $+\mathrm{R}$ \\
\hline \multicolumn{2}{|c|}{ Fluxo de Caixa 4} & $+/-\mathbf{a}$ & $+\mid-a_{11}$ & $+/-a_{12}$ & $+/-a_{13}$ & $+/-a_{14}$ & $+/-\mathrm{a}_{15}$ & $+/-a_{16}$ & $+\mid-a_{12}$ & $+1-a_{18}$ & $+1-\mathbf{a}_{19}$ & $+1-a_{20}$ \\
\hline
\end{tabular}

\footnotetext{
Este sub-total $e$ a soma dos investimentos fixos e capital de giro
}

${ }^{2} \mathrm{MOFV}+$ Enc $=$ måo-de-obra fixa e variável mais encargos sociais correspondente

${ }^{3}$ Este sub-total $t$ a soma dos itens que comprem o custo operacional

$\mathbf{4}_{\mathrm{a}}=\mathrm{R} \cdot(\mathrm{I}+\mathrm{C})$ 
sobre o investimento (R). Os métodos de avaliação que levam em conta o valor do dinheiro no tempo são representados por: a) valor presente dos fluxos liquidos do projeto; b) taxa interna de retorno e c) razão custo/beneficio (NORONHA, 1987). Desses métodos mais precisos, a TIR foi o método utilizado nesse trabalho.

Um projeto simples (ou convencional) é definido por:

$$
\left.\sum_{j=k+1}^{n} a_{j}\right\rangle-\sum_{j=0}^{k} a_{j}
$$

onde:

$$
\begin{aligned}
a_{j} & =\text { receita liquida do projeto (receita bruta - investimentos - custos) no } \\
& \text { ano } j \\
a_{0} & <0 \\
a_{j} & \leq 0 \text { para } j=1, \ldots, k \\
a_{j} & >0 \text { para } j=k+1, \ldots, n
\end{aligned}
$$

Para um projeto assim definido, a taxa interna de retorno real, não negativa e única $\alpha$, é aquela para a qual se verifica a igualdade:

$$
\sum_{j=0}^{n} a_{j}(1+\alpha)^{-j}=0
$$

A taxa interna de retorno $\alpha$, é aquela que iguala o valor presente (VP) ${ }^{3}$ a zero (Figura 1). A medida que se aumenta a taxa de desconto, dimuinui o valor presente do projeto. Como inferimos da Figura 1, a TIR é a maior taxa de desconto para a qual o projeto apresenta valor atual nåo negativo. Portanto, para taxas inferiores a taxa interna de retorno, as receitas futuras compensam o capital investido no sentido de que, se considerarmos 0 investimento inicial como resultante de um empréstimo a ser restituido a determinada taxa de desconto, as receitas futuras seriam mais do que suficientes para o resgaste do

${ }^{3} V P=\sum_{j=0}^{n} a_{j}(1+i)^{-1}$, onde $i=$ taxa de desconto 
emprestimo. Por conseguinte, em principio, um projeto será tanto mais desejável quanto maior a sua taxa interna de retorno, pois tanto maior seria a taxa de desconto que aceitariamos pagar pelo emprestimo do capital inicial. No caso da avaliaçăo de um projeto pelo critério da taxa interna de retorno, sua aceitaçăo, no sentido de ser economicamente desejável, ocorrera se a sua TIR for superior a uma dada taxa de desconto e que usualmente, é denominada de taxa minima de atratividade (FARO,1971).

Determinaçåo gráfica da taxa interna de retorno (IF)

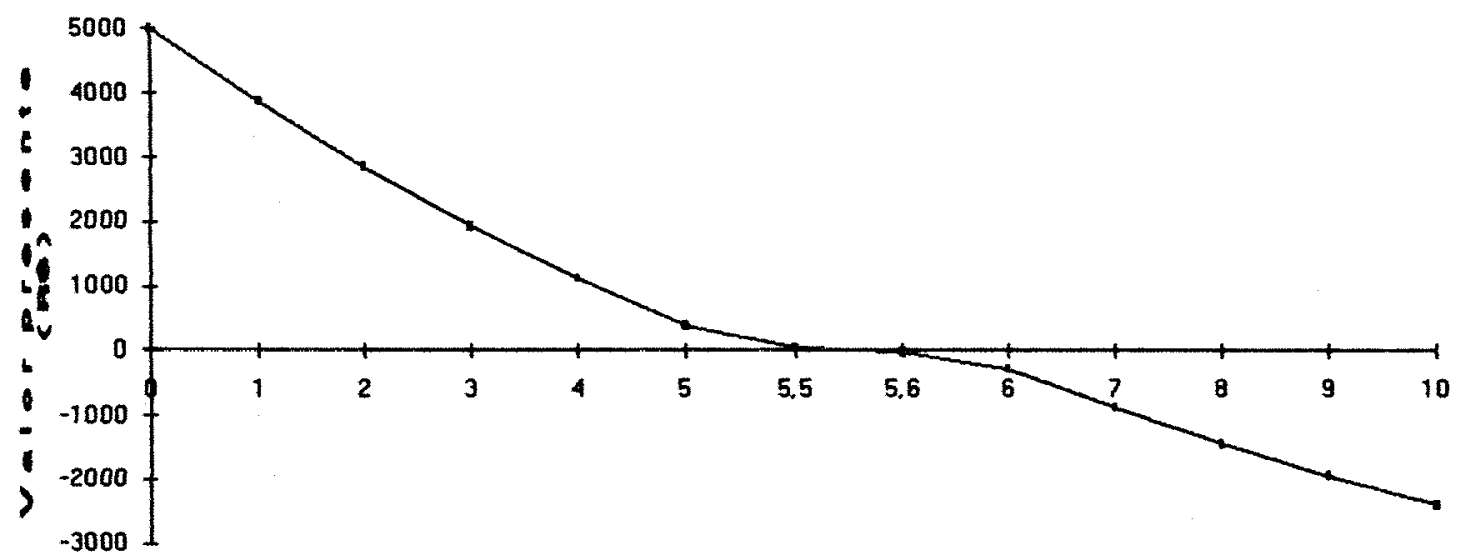

Taxededesconto (x)

Figura 1

Essa taxa de desconto é o fator pelo qual é julgada a atratividade de uma oportunidade de investimento, ou de projeto. Na realidade, a taxa de desconto é uma figura năo conhecida, mas pode ser estimada com precisăo suficiente, permitindo que a decisăo de investimento possa ser feita proxima do nivel ótimo. O resultado disso são duas decisð̌es que devem ser tomadas simultaneamente: a decisão de financiamento e a decisăo de investimento. A decisão de investimento está relacionada com a decisð̃o de financiamento porque a aceitação ou rejeiçăo do projeto de investimento depende de como o projeto será financiado. Como é sabido, a empresa é intermediária no processo de obtençăo de fundos de 
capital próprio e de terceiros. No curto-prazo, a taxa de juros ou de desconto usada na avaliaçăo do projeto de investimento é uma funçăo do custo de financiamento desse projeto. O custo financeiro é comumente chamado de custo de capital e é usualmente expresso como uma taxa anual.

O objetivo da empresa é a maximização da riqueza futura dos seus acionistas, o que equivale a maximizaçăo do seu VP. A maximização do VP da empresa envolve um fluxo de caixa futuro descontado através de uma taxa de juros determinada. Geralmente esta taxa de juros é igual ou ligeiramente maior do que o custo de capital marginal da empresa. $O$ principio do custo de oportunidade requer que os fundos de investimento da empresa, adquirido pelos acionistas ou pela agência financiadora, seja o melhor uso alternativo dentro das diversas opç̃es, isto é no projeto VP > 0 , onde todo o fluxo de caixa é descontado pelo custo marginal do capital. Alternativamente, o mesmo principio requer que o investimento em um projeto futuro tenha uma TIR maior que o custo de capital da empresa (assumindo nåo restriçåo no fomecimento de capital ). Se essas regras forem seguidas, supostamente o valor das açóes da empresa será maximizado ao longo do tempo (BUSSEY, 1982).

A dificuldade com o termo custo de capital reside no fato de que pode dar a entender, aos menos avisados, que existe uma taxa (custo) is a qual o capital pode ser obtido, que é independente do modo pelo qual o capital será empregado. Essa posiçăo é incorreta. O capital que está sendo empregado é fornecido pelos credores e investidores na expectativa de a empresa, agindo em seu nome, leve em conta as oportunidades que possuem para aplicar esse capital em oportunidades alternativas a taxas que variam com o risco. Nada de errado existe com o termo custo de capital, desde que corretamente interpretado (SOLOMO e PRINGE, 1981, p.298).

No momento atual da economia brasileira, muitas empresas exportadoras estăo conseguindo financiamento de longo-prazo atraves de eurobônus (títulos de longo prazo emitidos por empresas e bancos para captar dinheiro no mercado internacional), que possuem custo menor do que obter financiamento no mercado interno. Os juros praticados 
pelos grandes bancos são de 12\% a.a. (LUCCHESEI, 1995). Outro indicador que podera ser utilizado como parâmetro de avaliaçăo de projetos seriam os titulos do tesouro norteamericano ("treasury bonds") com prazo de 30 anos, que no dia trinta de julho de 1995 ofereciam um rendimento de 6,64 \% a.a. (GRADILONE, 1995 e OLIVEIRA, 1995).

\subsection{4) Determinação do ponto de equilibrio e do lucro bruto anual da unidade de processamento.}

O objetivo de encontrar o ponto de equilibrio é determinar o volume de produção ou a percentagem de capacidade instalada que iguala a receita total (RT) ao custo total (CF+CV) anual do projeto. O valor dessa variável (percentagem de capacidade instalada), será utilizado na análise de sensibilidade. O ponto de equilibrio pode ser encontrado da seguinte maneira:

$$
\mathrm{PE}=\frac{C F T}{R T-C V T}
$$

onde:

$\mathrm{PE}=$ percentagem da capacidade instalada;

$\mathrm{RT}=$ receita total anual da unidade de processamento, em reais;

$$
\text { onde: } \begin{aligned}
\mathrm{RT} & =\sum_{t=1}^{n} P_{t} * Q_{t} \\
\mathrm{P}_{\mathrm{i}} & =\text { preço do produto } \mathrm{i} \\
\mathrm{Q}_{\mathrm{i}} & =\text { quantidade do procuto } \mathrm{i}
\end{aligned}
$$

CFT = custo fixo total anual da unidade de processamento, em reais; onde: $\quad \mathrm{CFT}=\sum_{i=1}^{n} C F_{i}$

$$
\mathrm{CF}_{\mathrm{i}}=\text { Custo Fixo anual do produto } \mathrm{i}
$$


Os custos fixos do produto oneram a empresa obrigatoriamente, independente do nivel da produçåo obtida e logicamente dentro da capacidade operacional de produçăo instalada.

CVT = custo variavel total anual da unidade de processamento, em reais;

$$
\text { onde: } \begin{aligned}
\mathrm{CVT} & =\sum_{t=1}^{n} C V_{t} \\
\mathrm{CV}_{\mathrm{i}} & =\text { custo variável anual do produto } \mathrm{i}
\end{aligned}
$$

O custo variável é apresentado por produto, sendo que seu valor esta em função da quantidade produzida do produto.

O lucro bruto anual da unidade de processamento é definido por:

$$
\mathrm{LB}=\mathrm{RT}-\mathrm{CT}
$$

$$
\text { onde }: \mathrm{CT}=\mathrm{CFT}+\mathrm{CVT}
$$

$\mathrm{CT}=$ custo total anual da unidade de processamento, em reais;

O CT é o custo total de produçăo. Não estão incluidas as despesas operacionais administrativas e de vendas.

\subsection{5) Analise de Sensibilidade}

A análise de sensibilidade de um projeto e utilizada como uma forma de examinar o comportamento da rentabilidade do investimento, quando há variações nos itens considerados na estrutura de custo e/ou receita. Essas variaçðes por sua vez, permitem que os custos e/ou receitas variem, alterando desta forma os fluxos de caixa e proporcionando novas taxas internas de retorno. A comparaçăo das novas taxas encontradas com a obtida no caso-base, informa sobre a sensibilidade da taxa interna de retorno em relaçăo a variações 
daqueles itens componentes do custo e/ou receita. E uma tentativa de reduzir a incerteza quanto aos resultados obtidos.

Pela análise de sensibilidade pode-se avaliar, também, a possibilidade da existência de ociosidade e comparar os resultados com o caso que pressupõe a utilização de toda a capacidade. Para tanto, as alteraçőes devem ser introduzidas junto aos custos variáveis e receitas, mantendo-se o investimento total fixo.

Os itens de custo alterados foram os seguintes: matéria-prima, mão de obrafixa + variável + encargos, embalagem, eletricidade mais combustivel e capital de giro. A receita foi alterada isoladamente e conjuntamente com a matéria-prima e a embalagem. Por último, foi examinado o efeito da alteração do nivel da utilizaçåo da capacidade instalada. Em funçăo das alteraçðes dos custos e receitas, o fluxo de caixa é alterado. Para cada novo fluxo de caixa, é recalculada a taxa interna de retorno correspondente. A escolha dessas variáveis foi feita em função da sua importancia na estrutura de custos da unidade industrial.

\section{4) Impacto do projeto de investimento sobre o nfvel de emprego e renda no municfpio.}

Tanto para a exportaçăo quanto para o atendimento do mercado interno, a produçăo agricola da pequena ou da grande propriedade e o seu crescimento, passam a depender da existência de indústrias de insumos e máquinas agricolas e dos processos de elaboraçăo indústrial. O processo de intensificaçăo no uso do capital na produçăo agricola, leva a profundas modificaçóes nos tipos de empresas agricolas. Os grandes latifundios se transformam em modernas empresas capitalistas e a pequena produção ou é marginalizada ou se integra a $\mathrm{CAI}$ gerando uma camada de pequenos produtores capitalizados (SORJ, 1980).

Uma das razóes apontadas como básica no estabelecimento dos sistemas integrados (exemplo: plantadores de fumo da regiăo de Santa Cruz do Sul, no Rio Grande do 
Sul, a suinocultura e avicultura no ceste de Santa Catarina e a cultura do tomate no vale do São Francisco, na Bahia) é o elevado grau de risco que envolve a atividade agropecuária. Normalmente, essa forma de organizaçăo está associada à manutenção de grandes estruturas de produção, que pelas caracteristicas dos produtos, exigem a participação constante de mão-de-obra. Outro aspecto relevante é a maior possibilidade de acumulação que essa op̧åo oferece ao assegurar o fornecimento de matéria-prima a preços que garantem a transferência do excedente da produçåo rural para o setor industrial. Do ponto de vista do produtor rural, o aspecto mais importante é a garantia de venda de seus produtos, o que nåo ocorreria caso se estabelecesse como produtor independente. A integração pode ser vista quase como uma espécie de "etapa de produçăo" do setor industrial e a remuneraçăo paga aos produtores é praticamente equivalente à que ocorre nas relaçőes entre indústria e assalariados. $\grave{A}$ medida que os produtores se organizam, passam a deter algum poder de influência na fixaçåo de preços porém a niveis que ainda viabilizam o esquema de integraçåo (RAMALHO, 1988).

SANTOS (1991), ao estudar as áreas irrigadas no Nordeste, no sentido da sua organização no contexto da agroindústria, verificou uma predisposição em torno de $60 \%$ das sociedades de parceleiros (sistemas de parcelas nas áreas de colonizaçăo rural) em implantar uma agroindústria própria para processar sua produçăo agricola. Indiretamente, essas organizaçoes estavam questionando o modelo agroindustrial vigente, possivelmente porque os mecanismos de proteçăo ao produtor rural postos em prática têm se manifestado pouco eficientes. Isoladamente, os preços estabelecidos pelas agroindústrias para a matériaprima agroindustrial, foi o fator mais questionado pelas entidades de colonos, dentre os principais problemas existentes. Contudo, esse mesmo autor conclui que o modelo agroindustrial, via organizaçăo de parceleiros (os projetos de colonizaçăo săo divididos em parcelas com capacidade de sustentar uma familia) funcionará como um obstáculo à evasåo de rendas do meio rural para os grandes centros urbanos, já que o valor agregado pelo processo industrial serd pelo menos em parte apropriado pelos irrigantes locais, elevando, consequentemente, a rentabilidade de suas exploraçőes agropecuárias. $O$ beneficiamento ou 
industrializaçăo da produçăo agricola, através das cooperativas e associą̧øes, devem ser encaradas como um fator de integraçăo intersetorial e, portanto, de relevância no processo de desenvolvimento rural integrado.

Todo projeto de investimento gera empregos diretos $e$ indiretos os quais estăo relacionados com a capacidade operacional da fábrica. O primeiro efeito é mais fácil de se determinar que o segundo, pois o número de empregos diretos gerados faz parte da estrutura de custo do projeto. Já com relaçăo aos empregos indiretos, é possivel se fazer uma estimativa relativamente próxima com relaçăo à necessidade de măo-de-obra na atividade agricola propriamente dita, devido ao volume de matéria-prima necessária para que seja utilizada a capacidade instalada da inctústria. Os empregos indiretos gerados pelo projeto săo mais diffceis de serem identificados, tanto nas áreas que prestam serviços à agricultura (indústria para a agricultura), quanto nas atividades posteriores d industria (engarrafamento e distribuiçăo). No entanto, esses empregos indiretos mais dificeis de serem medidos terão pouco impacto no municipio de Vera Cruz, já que se supore que o produto sera engarrafado e distribuido por uma outra empresa que se localiza em Săo Paulo. 


\section{4) RESULTADOS ECONÔMICOS}

\section{1) Introdução}

Este capitulo descreve primeiramente a parte de engenharia do projeto, especificando a capacidade operacional da unidade produtiva, os equipamentos necessários (Tabela 27 e 28) e o cronograma de trabalho. Depois de conchuida esta etapa, são definidos os investimentos totais e o custo total de produção, a partir da definição descrita na metodologia. Esses itens formam a estrutura do fluxo de caixa do projeto, que será utilizado para determinar a TIR e a análise de sensibilidade do projeto como descrita na metodologia.

\section{2) Capacidade Minima da Unidade Processadora 4}

A quantidade de maracujá produzida na DIRA de Marilia vem crescendo nos últimos anos como pôde ser verificado na Tabela 5 do primeiro capítulo deste trabalho. Dentro da DIRA de Marilia, o município de Vera Cruz desponta como o principal município produtor, chegando a atingir o volume estimado de 5000 toneladas de maracujá na safra 94/95, de acordo com a AFRUVEC, sendo que dessa quantidade, 1300 toneladas se destinaram à indústria (aproximadamente $26 \%$ da produção). O cronograma da safra e da extraçăo estão descritos nos Quadros 1 e 2 . Como se pode observar, a safra de maracujá dura 9 meses. Para preencher o restante dos meses, escolheu-se o abacaxi como a fruta para ser processada, escolha essa feita em função da disponibilidade da matéria-prima próxima do município de Vera Cruz e da compatibilidade em se processar suco de maracujá e abacaxi na mesma planta industrial

\footnotetext{
4 Esta parte do estudo foi realizada com a colaboração do Instituto de Tecnologia de Alimentos (ITAL), da Secretaria da Agricultura, através do engenheiro mecânico Dr José Gasparino Filho.
} 
Com relaçăo ao fornecimento de abacaxi, a DIRA de Bauru é uma grande regiăo produtora desta fruta, chegando a atingir o volume de 14000 toneladas por ano (Instituto de Economia Agricola, 1994). Entretanto, a maior parte desta produção é destinada ao mercado "in natura".

De acordo com os Quadros 1 e 2, a fábrica ficará parada por dois meses (setembro e outubro) em função da falta de matéria-prima. Por isso o primeiro mês será reservado para férias coletivas e o segundo mês à manutençåo geral. Nos meses de dezembro e/ou janeiro poderá ser moído o maracujá ou abacaxi de acordo com a demanda pelos dois produtos no mercado.

Quadro 1. Cronograme da Safre

\begin{tabular}{|l|l|l|l|l|l|l|l|l|l|l|l|l|}
\hline Fntes & Dez & Jen & Fev. & Mar. & Abr. & Mio & Jun & sulto & Apost & Set & Out & Nov. \\
\hline $\mathbf{M a}^{1}$ & $\mathbf{X}$ & $\mathbf{X}$ & $\mathbf{X}$ & $\mathbf{X}$ & $\mathbf{X}$ & $\mathbf{X}$ & $\mathbf{X}$ & $\mathbf{X}$ & $\mathbf{X}$ & & & \\
\hline $\mathrm{Ab}^{2}$ & $\mathbf{X}$ & $\mathbf{X}$ & & & & & & & & & & $\mathbf{X}$ \\
\hline
\end{tabular}

$1_{\text {minacujh }}$ ebecaxi

Quadro 2. Cronograme de trabelho

\begin{tabular}{|c|c|c|c|c|c|c|c|c|c|c|c|c|}
\hline Frutes & Dez & Ima. & Fev. & M. & Abs. & Mio & Jon & Julno & Apost & Set & Out & Nov. \\
\hline $\mathrm{Ma}^{1}$ & $X$ & $X$ & $X$ & $X$ & $X$ & $\mathbf{X}$ & $\mathbf{X}$ & $\mathbf{X}$ & $\mathbf{X}$ & 3 & 4 & \\
\hline $\mathrm{Ab}^{2}$ & & & & & & & & & & 3 & 4 & $x$ \\
\hline
\end{tabular}

De acordo com as informaçós obtidas no ITAL a unidade de processamento deve ter uma capacidade minima de processamento de $2500 \mathrm{~kg}$ de matériaprima por hora, o que equivale a 520 ton/mês, correspondendo a 4680 tano de maracujá e 520 tano de abacaxi (Figuras 2 e 3). Essa decišo foi baseada nas seguintes razres: existência no mercado de equipamentos disponiveis para montar a unidade industrial com esta capacidade operacional, e quantidade de matéria-prima dispontvel no munictpio. Em termos industriais, esta unidade é de pequeno porte, pois no caso da indústria processadora 


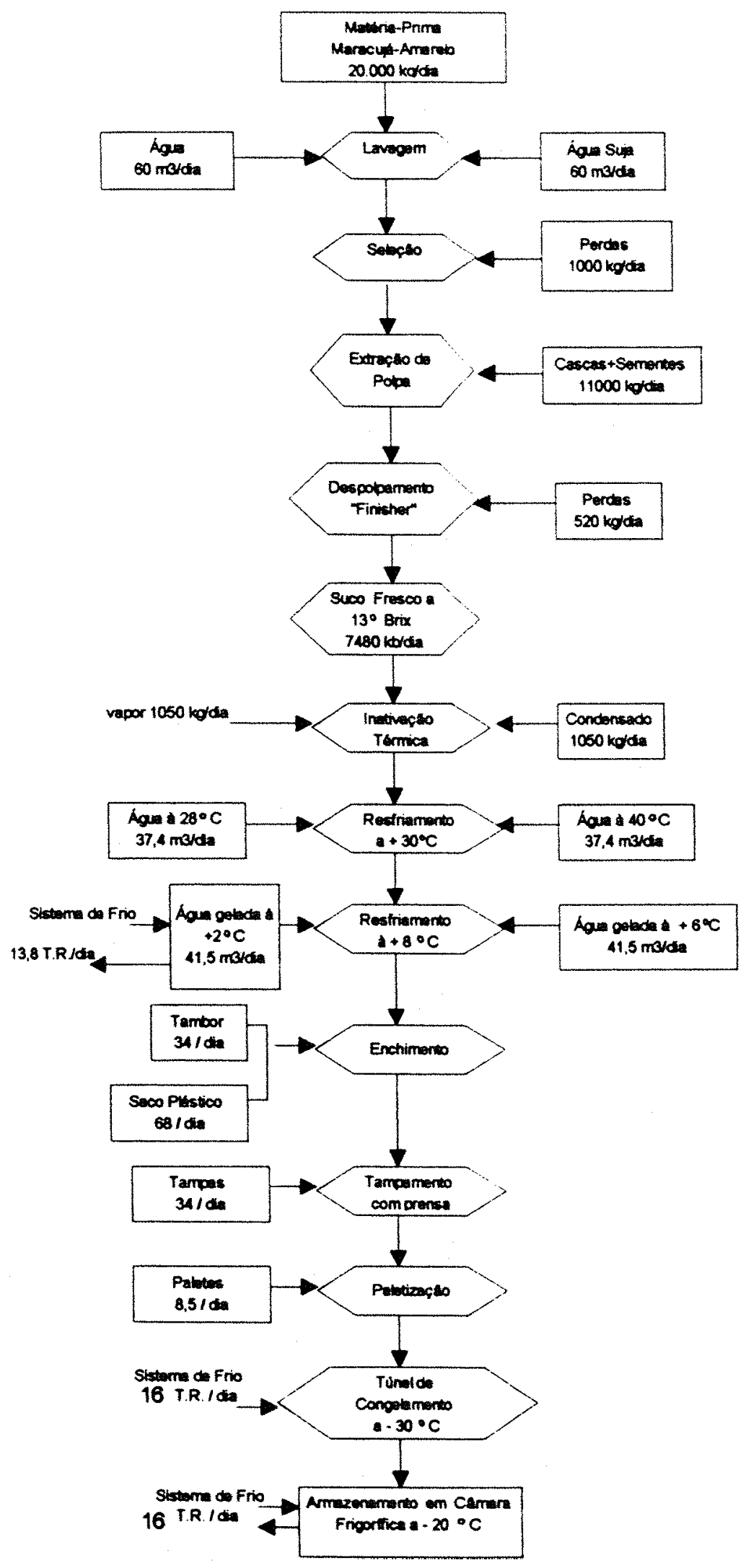

Fig.2 Fluxograma Quantitativo Básico para Produçăo de Suco de Maracujá Congelado 


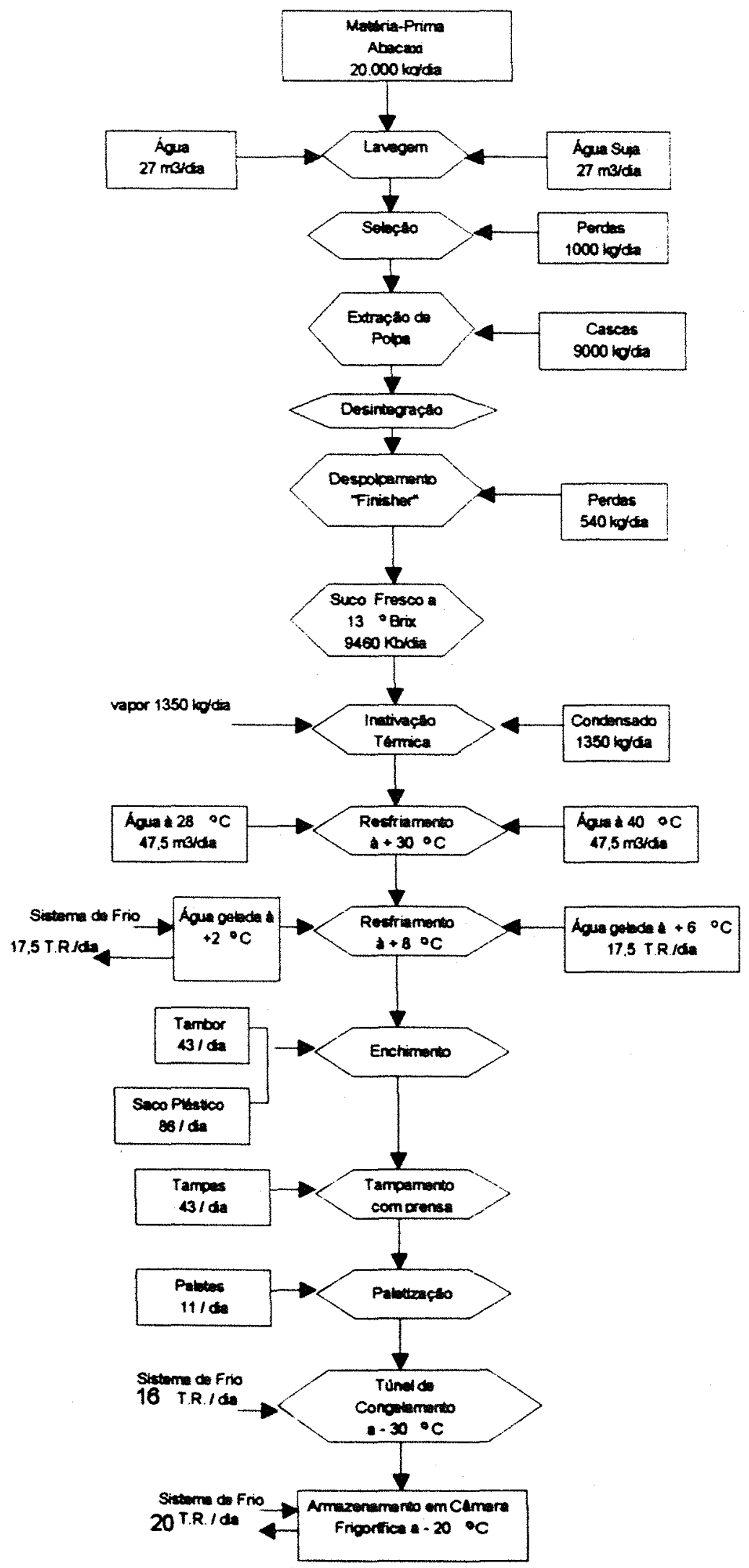

Fig. 3 Fluxograma Quantitativo Básico para Produçăo de Suco de Abecaxo Congelado 


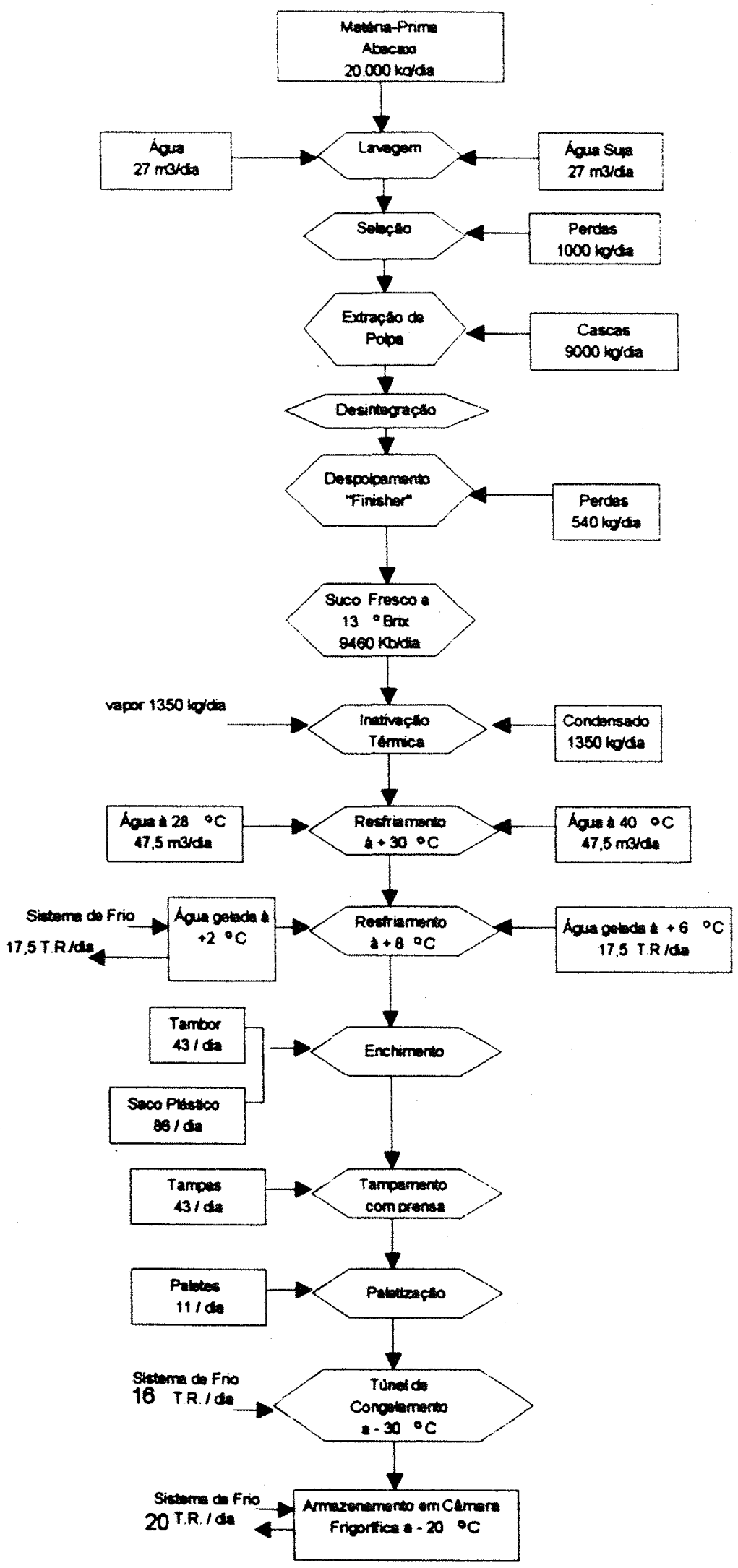

Fig. 3 Fluxograma Quantitativo Básico para Produçăo de Suco de Abacaxj Congalado 
de abacaxi, a capacidade minima de produçăo é de $5000 \mathrm{~kg}$ M-P/h (matéria-prima/hora). A unidade processadora de suco produzirá suco de maracuja e de abacaxi congelado visando o mercado interno. É também possivel exportar este tipo de produto, sendo no entanto mais comum a exportação de sucos na forma de concentrados. Para tal, entretanto, seria preciso utilizar equipamentos de evaporaça ou concentradores, o que provocaria um aumento substancial nos investimentos.

\section{3) Estruturn do Fluxo de Caixa}

\subsection{1) Introduc:}

Nesta parte do estudo sertio apresentados e discutidos os resultados econômicos da unidade industrial para a industrializaçăo de sucos congelados. Para efeito de cálculo dos custos de produçăo, pressupőe-se que a unidade incustrial estará operando 260 dias por ano em regime de um turno diário de trabalho. Para atender a capacidade operacional de produça anual, a unidade industrial necessitara de 4680 toneladas de maracujá e 520 toneladas de abacaxi, e deverá obter, resultante do processamento, os produtos indicados nas Tabela 12 e 13, com suas respectivas quantidades e participaçăo no total produzido. Os produtos serớo comercializados em tambores de $220 \mathrm{~kg}$.

Tabela 12 - Distribuiça quantitativa e percentual da produç tuo da unidade industrial, por produto.

\begin{tabular}{lcc} 
Discriminacto & Quantidade produzida (kg) & \% no total produzido \\
\hline Suco de Maracuje congelado & $1.750 .320,0$ & 87.7 \\
Suco de Abacaxi congelado & $245.960,0$ & 12,3 \\
\hline Totol & $1.996 .280,0$ & 100.0 \\
\hline
\end{tabular}

Fonte: SEME/SEQ - ITAL 
Tabela 13 - Necessidade de embalagem (tambores de $220 \mathrm{~kg}$ com saco plastico de $100 \mu \mathrm{m}$ duplo).

Produtos Número de embelingens

Suco de maracujk congelado $\quad 7956$

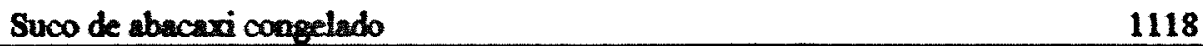

Total

9074

Fonte: SEME/SEQ - TTAL

\subsection{2) Estimativas do investimento fixo e de capital de giro para a industrialização do maracuja e do abacaxi.}

Os investimentos necessários para a implantaç̧o da unidade industrial foram estimados a partir dos fluxogramas quantitativos básicos apresentados anteriormente pelas figuras 2 e 3. O investimento total foi subdividido em dois itens: os investimentos propriamente ditos e o capital de giro. A Tabela 14 indica o investimento fixo previsto, segundo os itens que o compoem, enquanto na Tabela 15 figuram os valores correspondentes ao capital de giro. O capital de giro permite iniciar o processo produtivo da empresa. Em sua estimativa levam-se em conta as quantidades minimas de venda, os prazos de entrega, a indivisibilidade dos itens de despesas e a capacidade de estocagem da empresa.

Tabela 14 - Estimativa do investimento necessario para a implantacto de uma unidsde industrial de processamento de suco de maracujia e de abacaxi congelados.

\begin{tabular}{|c|c|}
\hline Invertimento fixo & Rs: \\
\hline - Estudo e Projetos & $6.000,00$ \\
\hline - Terreno e obra de terraplansgem & $22.200,00$ \\
\hline - Redes externss, eletricas água e esgoto & $38.634,00$ \\
\hline - Obras civis & $257.563,00$ \\
\hline \multicolumn{2}{|c|}{ - Equipementos para o processamento de sucos de } \\
\hline maracuje e abacaxi & $234.840,00$ \\
\hline - Rquipamentos auxiliares & $130.609,00$ \\
\hline - Equipamentos de laboratorios & $11.535,00$ \\
\hline
\end{tabular}


(contimuscha)

- Vefculos

$47.871,00$

- Móveis e instalaçes de escritórios

$8.992,00$

- Paletes

$4.136,00$

- Montagens e instalaçres

$56.548,00$

- Imprevistos

$40.946,00$

Total

$859.874,00$

Total em USS 1

TUS\$ 1,00 = R\$ 0,833 12/02/95

Fonte: SEME/SEQ - ITAL

Tabela 15 - Estimativa do Capital de giro necessatrio para a implantaçno de uma unidadade industrial de processamento de suco de marscujá e de abacaxi congelados.

\begin{tabular}{lc} 
Capital de Giro & RS \\
\hline - Matéria-prima & $13.600,00$ \\
- Combustiveis & 594,00 \\
- Material de Limpezs & 665,00 \\
- Produto acabado & $140.205,00$ \\
- Pecas de reposição & $3.770,00$ \\
- Material de embalagem & $24.918,00$ \\
- Paletes & 414,00 \\
- Caimas e bancos & $2.198,00$ \\
\hline - Total & $186.364,00$ \\
Total en USS & $223,726.00$ \\
\hline
\end{tabular}

IUSS $1,00=$ RS $0,833 \quad 12 / 02 / 95$

Fonte: SEMR/SBQ - TTAL

A somatória do investimento fixo e do capital de giro, fornece o valor do investimento total, que no referido estudo corresponde a RS 1.046.238,00 ou equivalente a US\$ $1,255,988.00$. 


\subsection{3) Resultados do Caso-base e Analise de Sensibilidade}

Em primeiro lugar, consideramos o fluxo de caixa para utilizaçăo plena da capacidade instalada (caso-base), formado pelo investimento, capital de giro, receita total e custo operacional (Tabelas 16 e 17). A TIR obtida foi de $25,72 \%$, sendo que esse valor năo é muito alto quando comparado com os projetos agroindústriais vistos no item 2.4. A seguir foram feitas variações nos seguintes itens: materia-prima, material de embalagem, măo de obra fixa + variável + encargos, energia elétrica + combustiveis, capital de giro, receita total, receita total e matéria prima, receita total e embalagem e utilizaçăo da capacidade instalada. Os resultados estăo apresentados na Tabela 18.

Tabela 16. Estrutura do Fluxo de Caixa

llens Em R\$

a) Investimentos

a 1) Edificaçōes

Redes externas, elétricas e esgoto

$38.634,00$

Obras civis

257.563 .00

Sub-total

$296.197,00$

a2) Equipamentos

Equipamentos para processamento de suco

$234.840,00$

de maracujá e abacaxi

Equipamentos auxiliares

$130.609,00$

Equipamentos de laboratónios

$11.535,00$

Móveis e instalaçōes de escritórios $\quad 8.992,00$

Montagens e instalaçōes $\quad \mathbf{5 6 . 5 4 8 , 0 0}$

Sub-total

442.524,00

a3) Veiculos

Veículos

47.871 .00

a4) Paletes

Necessidade de 20 jogos de paletes, cada jogo

contendo 11 paletes totalizando 220 paletes

( $R \$ 18,80 /$ palete)

a5) Outros

Imprevisto (5\% do investimento fbxo) $\quad 40.946,00$

Estudos do projeto

6.000 .00

Terreno e obra de terraplanagem

$22.200,00$

Sub-total

$69.146,00$

Total

859.874 .00

(continua) 
(continuaçăo)

b) Capital de Giro

b1) matéria-prima

É formado pela quantidade de maracujá necessário para

iniciar o processamento segundo o fluxograma 2 (2O/dia).

Como a indústria terá a capacidade de estoque de matéria-prima para 4 dias, o total de matéria-prima será de $80 \mathrm{t}$, a um preço de $\mathrm{R} \$ 170,00 \mathrm{n}$.

13.600 .00

b2) Produto Acabado

Representa a quantidade de produto acabado que

possível armazenar em um rodada. Segundo a tabela 2.

é possivel produzir 34 tambores (Tb)/dia, que multiplicado

por 22 dias (lempo necessário para preencher o local de

armazenamento $)=748 \mathrm{~Tb}(220 \mathrm{~kg} / \mathrm{Tb})$. O preço do suco

corresponde a $\mathrm{R} \$ 0,852 / \mathrm{kg}$.

$140.205,00$

b3) Peças de Reposiçăo

Corresponde a $1 \%$ sobre o investimento em equipamentos

3.770 .00

b4) Material de embalagem, combustivel e material de limpeza

Corresponde a tambores, sacos plásticos, combustível e

material de limpeza.

26.177 .00

b5) Paletes

Corresponde a um conjunto inicial mais um conjunto

de reserva, cada conjunto de paletes é formado por 11

paletes e cada palete corresponde a 4 tambores

414,00

b6) Bancos e Caixas

Corresponde a $5 \%$ sobre os itens do capital

de giro, com exceça dos produtos

acabados.

$2.198,00$

Total

$186.364,00$

c) Recelta

produção de suco de maracujúh $=7946$ tb

produção de suco de abacaxi $=1118$ tb

preço/hb $=\mathbf{R} \$ 209,90$ de maracujá

preço/kb $=R \$ 118,80$ de abacaxi

Tolal

1.802 .782 .00

(continua) 
(continuação)

\begin{tabular}{|c|c|c|}
\hline & Em R\$ & \\
\hline \multicolumn{3}{|l|}{ d) Custo Operacional } \\
\hline \multicolumn{3}{|l|}{ d1) Māo de obra fixa + variável + encargos } \\
\hline Māo de obra fixa & $81.948,00$ & \\
\hline Encargos & 48.677 .00 & \\
\hline Mão de obra variável do maracujá & 17.680 .00 & \\
\hline Encargos & $10.454,00$ & \\
\hline Māo de obra variável do abacaxi & 2.480 .00 & \\
\hline Encargos & $1.521, \infty$ & \\
\hline Sub-total & & 162.760 .00 \\
\hline \multicolumn{3}{|l|}{ d2) Matéria-prima } \\
\hline \multicolumn{3}{|c|}{$\begin{array}{l}\text { O preço da matéria-prima do maracujá e abacaxi é } \\
\text { respectivamente de } \mathrm{R} \$ 170,00 \text { e } \mathrm{R} \$ 120,00 \text { a tonelada. } \\
\text { A fábrica irá trabalhar } 234 \text { dias com maracujá e } 26 \text { dias } \\
\text { (1 mês) com o abacaxi. Segundo o fluxograma } 2 \text { e } 3 \text {, será } \\
\text { preciso moer } 20 \text { vdia de matéria-prima. }\end{array}$} \\
\hline matéria-prima maracujá & $795.600,00$ & \\
\hline matéria-prima abacaxi & $62.400,00$ & \\
\hline \multirow{2}{*}{\multicolumn{3}{|c|}{ d3) Embalagem }} \\
\hline & & \\
\hline Material de embalagem para o maracujá & $230.520,00$ & \\
\hline Material de embalagem para o abacaxi & $32.393,00$ & \\
\hline \multirow{2}{*}{\multicolumn{3}{|c|}{ d4) Combustivel mais energia }} \\
\hline & & \\
\hline Combustivel para o maracujä & $14.406,00$ & \\
\hline Combustivel para o abacaxi & $1.970,00$ & \\
\hline Energia elétrica para o maracujá & 38.399 .00 & \\
\hline Energia elétrica para o abacaxi & $5.385,00$ & \\
\hline Subtotal & & $60.160,00$ \\
\hline \multicolumn{3}{|l|}{ d5) Outros } \\
\hline Manutenção (maracuja) & $15.259,00$ & \\
\hline Manutençāo (abacax) & $2.140,00$ & \\
\hline Água para o maracujá & 100.809 .00 & \\
\hline Água para o abacaxi & $14.139,00$ & \\
\hline Paletes para o maracujá & 725,00 & \\
\hline Paletes para o abacaxi & 95,00 & \\
\hline Material de limpeza para o maracuja & 10.101 .00 & \\
\hline Material de limpeza para o abacaxi & $1.417,00$ & \\
\hline Despesas gerais para o maracujá & 10.392 .00 & \\
\hline Despesas gerais para o abacaxi & $1.457,00$ & \\
\hline Despesas Gerais fixas & $10.133,00$ & \\
\hline Seguros & $9.056,00$ & \\
\hline Sublotal & & $175.723,00$ \\
\hline Total & & $1.519 .556,00$ \\
\hline
\end{tabular}


Tabela 17 Esutura do Fluxo de Caixa do Caso Bese

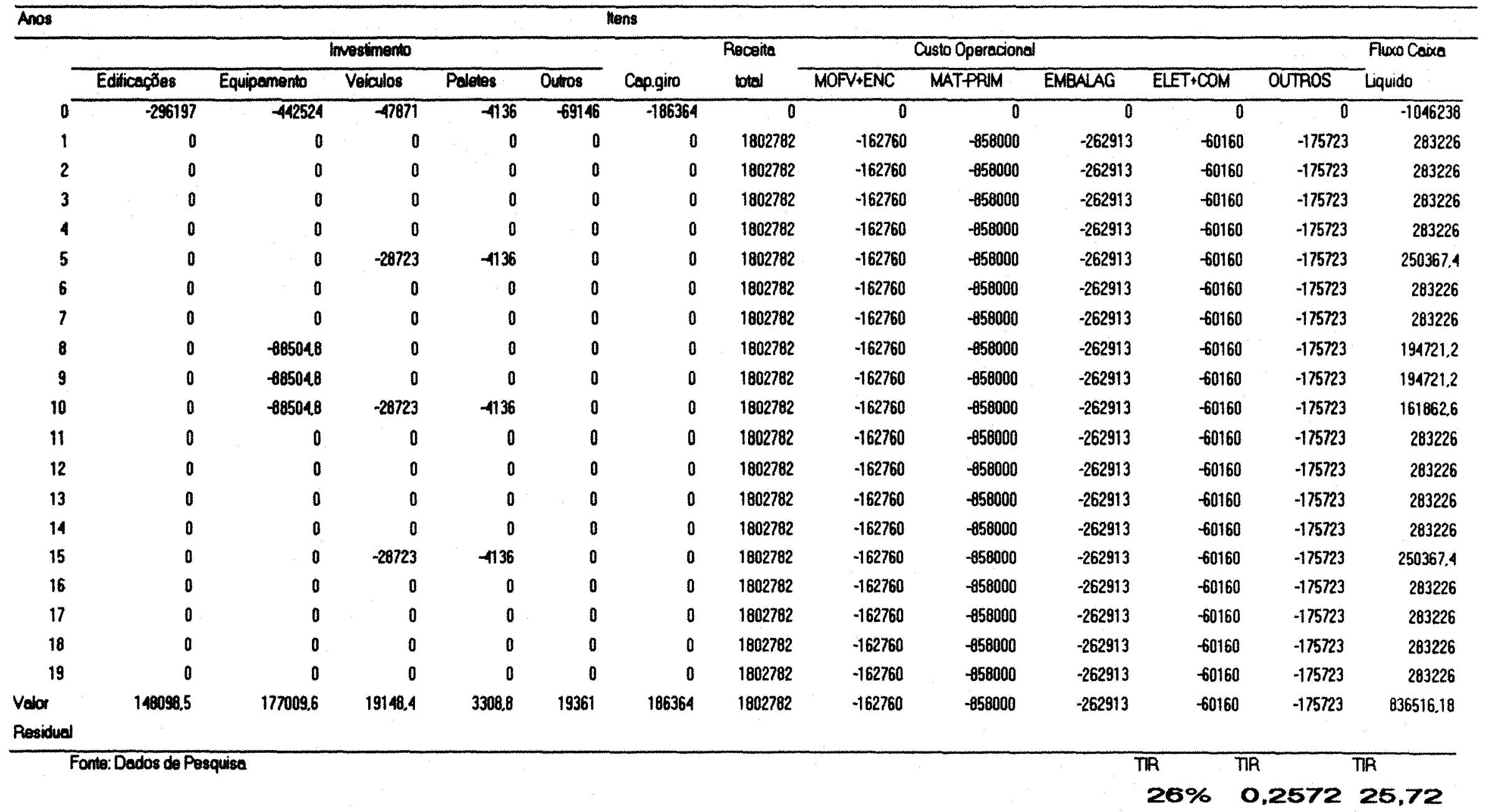


Tabela 18 - Resultados das antises de sensibilidades da TIR a variaçoes nos valores de diversos componentes do fluxo de crix da unidade de industrializafilo de maracuja e de abacaxi congelados.

\begin{tabular}{|c|c|c|}
\hline Componentes do thuxo de crixa & Variacto $(\%)$ & $\operatorname{TIR}(\%$ sa) \\
\hline Caso base & $\mathbf{0}$ & 25,72 \\
\hline \multirow[t]{6}{*}{ Matéria-prima } & -15 & 38,36 \\
\hline & -10 & 34,14 \\
\hline & -5 & 29,89 \\
\hline & 5 & 21,28 \\
\hline & 10 & 16,89 \\
\hline & 15 & 12,41 \\
\hline \multirow[t]{6}{*}{ Material de embalagem } & -15 & 29,55 \\
\hline & -10 & 28,24 \\
\hline & -5 & 26,92 \\
\hline & 5 & 24,29 \\
\hline & 10 & 22,96 \\
\hline & 15 & 21,63 \\
\hline \multirow[t]{6}{*}{ Mho de obra fix + variável + encargos } & -30 & 30,48 \\
\hline & -20 & 28,86 \\
\hline & -10 & 27,24 \\
\hline & 10 & 23,97 \\
\hline & 20 & 22.33 \\
\hline & 30 & 20,68 \\
\hline \multirow[t]{4}{*}{ Energia elétrica + combusttveis } & -20 & 26,81 \\
\hline & 10 & 25,01 \\
\hline & 20 & 24,40 \\
\hline & 30 & 23,80 \\
\hline \multirow[t]{4}{*}{ Capital de giro } & -20 & 26,60 \\
\hline & -10 & 26,10 \\
\hline & 10 & 25,14 \\
\hline & 20 & 24,69 \\
\hline \multirow[t]{3}{*}{ Receits total } & -5 & 16,44 \\
\hline & 5 & 34,56 \\
\hline & 10 & 43,40 \\
\hline
\end{tabular}




\begin{tabular}{|c|c|c|}
\hline Receita total & 5 & 26,04 \\
\hline e matéria-prims & 10 & \\
\hline Receita total & 10 & 26,48 \\
\hline e matéria prima & 20 & \\
\hline Receita total & 5 & 31,97 \\
\hline e embalagem & 10 & \\
\hline Receita total & 10 & 38,26 \\
\hline e embalagem & 20 & \\
\hline $\begin{array}{l}\text { Utilizaçato de } 70 \% \text { da capacidade } \\
\text { instalada }\end{array}$ & & 11,75 \\
\hline $\begin{array}{l}\text { Utilizaçăo de } 80 \% \text { da capacidade } \\
\text { instalada }\end{array}$ & & 16,80 \\
\hline $\begin{array}{l}\text { Utilizaçro de } 90 \% \text { da capacidade } \\
\text { instalada }\end{array}$ & & 21,24 \\
\hline
\end{tabular}

A sensibilidade da TIR em funçåo da variaçåo dos componentes do fluxo de caixa foi analisada de acordo com o seu grau decrescente de sensibilidade. A receita total foi - componente que mais influenciou a TIR. Uma variaçăo desse componente em $5 \%$ tanto para mais como para menos, faz com que a TIR varie de $16,44 \%$ a $34,56 \%$. O principal item do custo que influencia a TIR é o que se refere à matéria-prima, o qual representa $60 \%$ do custo total. Uma variaçăo de $15 \%$ do custo da materia-prima para mais e para menos faz com que a TIR varie de $12,41 \%$ a $38,36 \%$. Quando os componentes, receita total e custo da matéria-prima, variam o seu valor de mais $5 \%$ e mais $10 \%$ conjuntamente, o valor da TIR passa a ser de $26,04 \%$. Quando esses mesmos componentes variam isoladamente na mesma magnitude, a TIR passa ser de $34,56 \%$ e de $16,89 \%$ respectivamente. 
A TIR mostrou-se bastante sensivel a variaçôes na capacidade instalada da fabrica ( $90 \%, 80 \%$ e $70 \%$ ), o que provocou taxas internas de retomo de $21,24,16,80 \%$ e $11,75 \%$ respectivamente.

Os outros itens que fazem parte do custo operacional nåo influenciaram significativamente a TIR. Quando varia conjuntamente e isoladamente para cima a receita total e o custo de embalagem em $5 \%$ e $10 \%$, o valor da TIR passa a ser $31,97 \%, 34,56$ e $22,96 \%$ respectivamente. Segundo os técnicos do ITAL, outros tipos de unidades agroindustriais apresentam uma TIR com maior sensibilidade a variaçőes da energia elétrica mais o combustivel ou do material de embalagem, como por exemplo indústrias de desidratados. Os resultados mostraram que a TIR é pouco sensivel a variaçăo no capital de giro. De $-20 \%$ para $+20 \%$ do valor do capital de giro, A TIR passou de $26,60 \%$ para $24,69 \%$.

4.4) Estimativa da receita total, do custo total e unithrio e do lucro bruto amual do empreendimento.

\subsection{1) Estimativa do Custo Total e Unitario dos Produtos industrializados.}

Os custos fixos e variáveis foram calculados segundo a metodologia apresentada no último capitulo.

Tabela 19 - Rstimativa do custo fixo amual necesshrio para implantacto de uma unidade industrial de processamento de suco de maracuja e de abacaxi congelados.

\begin{tabular}{lccc}
\hline Custo Fixo Amual & RS & \\
\hline - Mulo de obra fixa & $\mathbf{8 1 . 9 4 8 , 0 0}$ & \\
- Encargos & $48.677,00$ & \\
- Depreciaç5 & 62.982 .00 & \\
- Segaros & $9.056,00$ & \\
\hline
\end{tabular}




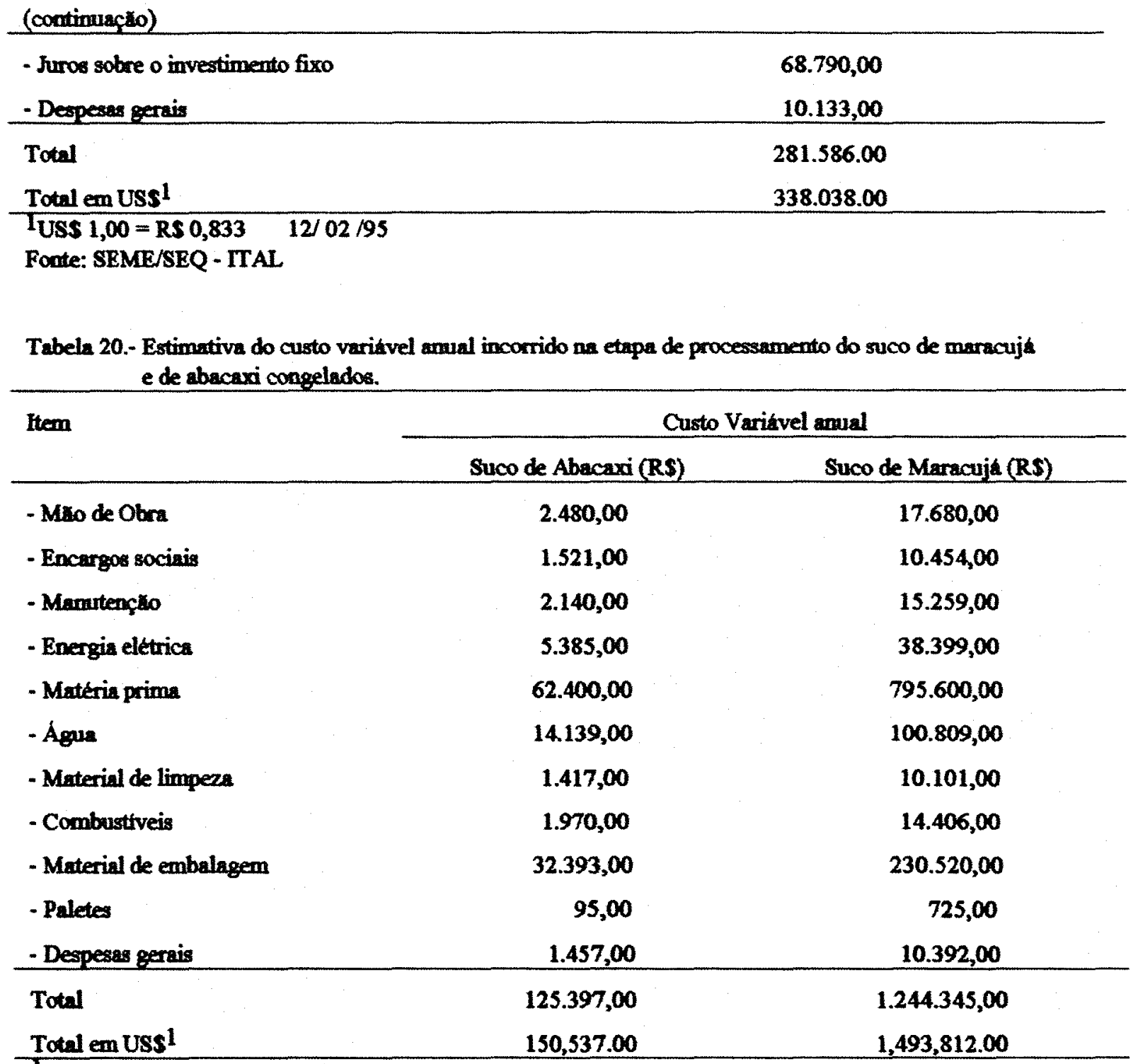

IUS\$ $1,00=$ RS 0,833 12/02/95

Fonte: SEME/SEQ - ITAL

O custo total (CT) é determinado pela soma do custo fixo (Tabela 19) e do custo variável (Tabela 20) de produção. O custo unitário, por sua vez, é obtido quando se divide o custo total de produção pela quantidade de produto produzida. Para calcular o CT do maracujá e do abacaxi, é preciso utilizar um critério de rateio do custo fixo, esse critério é em funçăo das caracteristicas especiais do projeto e dos produtos a serem produzidos e comercializados e cujo valor é determinado pela participaçăo do produto no volume total 
produzido pela unidade de processamento. Dessa forma, ao suco de maracuja congelado foram alocados $87,7 \%$ e ao suco de abacaxi congelado, $12,3 \%$ do custo fixo total.

Sendo assim o custo total e unitário da suco de maracujá e do abacaxi congelado foram calculados em:

$$
\begin{aligned}
& C T_{m}=R \$ 246.951,00+R \$ 1.244 .345,00 \\
& C_{m}=R S 1.491 .296,00
\end{aligned}
$$

onde:

$$
\mathrm{CT}_{\mathbf{m}}=\text { custo total do maracuja }
$$

Logo, para se obter o custo unitário de produção de suco de maracujá congelado $\left(\mathrm{CTMe}_{\mathrm{m}}\right)$ é só dividir $\mathrm{CT}_{\mathrm{m}}$ pela produçăo anual de suco maracujá congelado, em números de tambores, conforme epecificado na tabela 12:

$$
\mathrm{CTMe}_{\mathrm{m}}=\frac{R \$ 1.491 .296,00}{7.956 \text { tambores }}=R \$ 187,44 / \text { tambor }
$$

De maneira análoga foi também calculado o custo total do abacaxi.

$$
\begin{aligned}
& \mathrm{CT}_{\mathrm{a}}=\mathrm{RS} 34.635,00+\mathrm{RS} 125.397,00 \\
& \mathrm{CT}_{\mathrm{a}}=\mathrm{RS} 160.032,00
\end{aligned}
$$

Logo, o custo unitário de produção do suco de abacaxi congelado (CTMe $\left.{ }_{a}\right)$ foi o seguinte:

$$
\mathrm{CTMe}_{\mathrm{a}}=\frac{R \$ 125.397,00}{1118 \text { tambores }}=R \$ 112,16 / \text { tambor }
$$


Assim, o custo total do empreendimento da industrializaçăo de sucos congelados, é obtido pela somatória do custo fixo e dos custos variáveis especifloos de cada prochuto (CVm - custo variável do maracujá e CVa - custo variável do abacaxi) ou seja:

$$
\begin{aligned}
& \mathrm{CT}_{(\mathrm{a}+\mathrm{m})}=\mathrm{CF}_{(\mathrm{a}+\mathrm{m})}+\mathrm{CVm}+\mathrm{CVa} \\
& \mathrm{CT}_{(\mathrm{a}+\mathrm{m})}=\mathrm{R} \$ 281.586,00+\mathrm{R} \$ 1.244 .345,00+\mathrm{R} \$ 125.397,00 \\
& \mathrm{CT}_{(\mathrm{a}+\mathrm{m})}=\mathrm{R} \$ 1.651 .328,00
\end{aligned}
$$

\subsection{2) Estimativa da Receita Total e do Lucro Bruto Anual do Empreendimento e do seu Ponto de Equilibrio.}

Para a determinação da Receita Total da unidade produtora de sucos congelados, utilizou-se como referência os preços de venda no atacado, vigentes no mercado interno. Dessa forma, os preços de venda estabelecidos são os que se seguem:

- suco de maracujá congelado em tambor de $220 \mathrm{~kg}=\mathrm{R} \$ 209.90 /$ tambor

- suco de abacaxi congelado em tambor de $220 \mathrm{~kg}=\mathrm{RS} 118,80 /$ tambor

Esses preços proporcionam uma margem de lucro sobre o custo total de produçăo de $12 \%$ para os produtos e para o empreendimento como um todo. Essa margem foi calculada em funçăo do custo unitário do suco de maracuja, segundo os técnicos do ITAL a margem de lucro de uma agroindústria normalmente varia entre 8 a 15\%. Considerando-se os preços e quantidades produzidas de cada produto, temos as receitas parciais e total:

a) $\mathrm{RT}_{\mathrm{m}}=\mathrm{P}_{\mathrm{m}} * \mathrm{Q}_{\mathrm{m}}$, para o suco de maracujá congelado em tambores

onde:

$\mathrm{RTm}=$ receita total do maracujé

$\mathrm{Pm}=$ preço por tambor de suco de maracujá congelado

Qm = quantidade vendida de tambores de suco de maracujá congelado 
b) $\mathrm{RT}_{\mathrm{a}}=\mathrm{P}_{\mathrm{a}} * \mathrm{Q}_{\mathrm{a}}$, para o suco de abacaxi congelado em tambores

onde:

$\mathrm{RTa}=$ receita total do abacaxi

$\mathrm{Pa}=$ preço por tambor de suco de abacaxi congelado

$\mathrm{Q} \mathbf{a}=$ quantidade vendida de tambores de suco abacaxi congelado

Substituindo-se os valores correspondentes, tem-se :

$$
\begin{aligned}
& \mathrm{RT}_{\mathrm{m}}=\mathrm{R} \$ 209,90 * 7.956=\mathrm{R} \$ 1.669 .964,00 \\
& \mathrm{RT}_{\mathrm{a}}=\mathrm{R} \$ 118,80 * 1.118=\mathrm{R} \$ \quad 132.818,00
\end{aligned}
$$

Portanto, a receita total (RT) do empreendimento de industrialização de sucos congelados é dada por :

$$
\begin{aligned}
& \mathrm{RT}=\mathrm{RT}_{\mathrm{m}}+\mathrm{RT}_{\mathrm{a}}=\mathrm{R} \$ 1.669 .964,00+\mathrm{RS} 132.818,00 \\
& \mathrm{RT}=\mathrm{R} \$ 1.802 .782,00
\end{aligned}
$$

O lucro bruto (LB) da indústria como um todo é definido como a receita total (RT) menos o custo total (CT) ou seja:

$$
\mathrm{LB}=\mathrm{RT}-\mathrm{CT}
$$

substituindo-se os valores correspondentes encontrados anteriormente, tem-se :

$$
\begin{aligned}
& L B=R S 1.802 .782,00-R S 1.651 .328,00 \\
& L B=R \$ 151.454,00
\end{aligned}
$$

Com os dados até então obtidos, pode-se determinar o ponto de equilibrio do empreendimento de industrializaçăo de sucos congelados. Essa medida mostra a que nivel da produção o custo total e a receita total da unidade industrial são igualado $(C T=R T)$, num determinado ano de produçăo. 
O ponto de equilibrio (P.E.) é definido matematicamente por:

P.E. $=\frac{C F T}{R T-C V T}$

Substituindo-se os valores correspondentes, tem-se:

P.E. $=\frac{R \$ 281 \cdot 586,00}{R \$ 1 \cdot 802 \cdot 782,00-R \$ 1369 \cdot 742,00}=0,6502=65,02 \%$

Esses resultados correspondem a uma produção anual de 5.167 tambores de $220 \mathrm{Kg}$ de suco de maracujá congelado e de 756 tambores de $220 \mathrm{~kg}$ de suco de abacaxi congelado.

A representaçăo grafica do ponto de equilibrio (PE) é mostrada na figura 4.

Determinação do ponto de equilibrio (PE) da indústria de sucos congelados em termos de capacidade instal ada

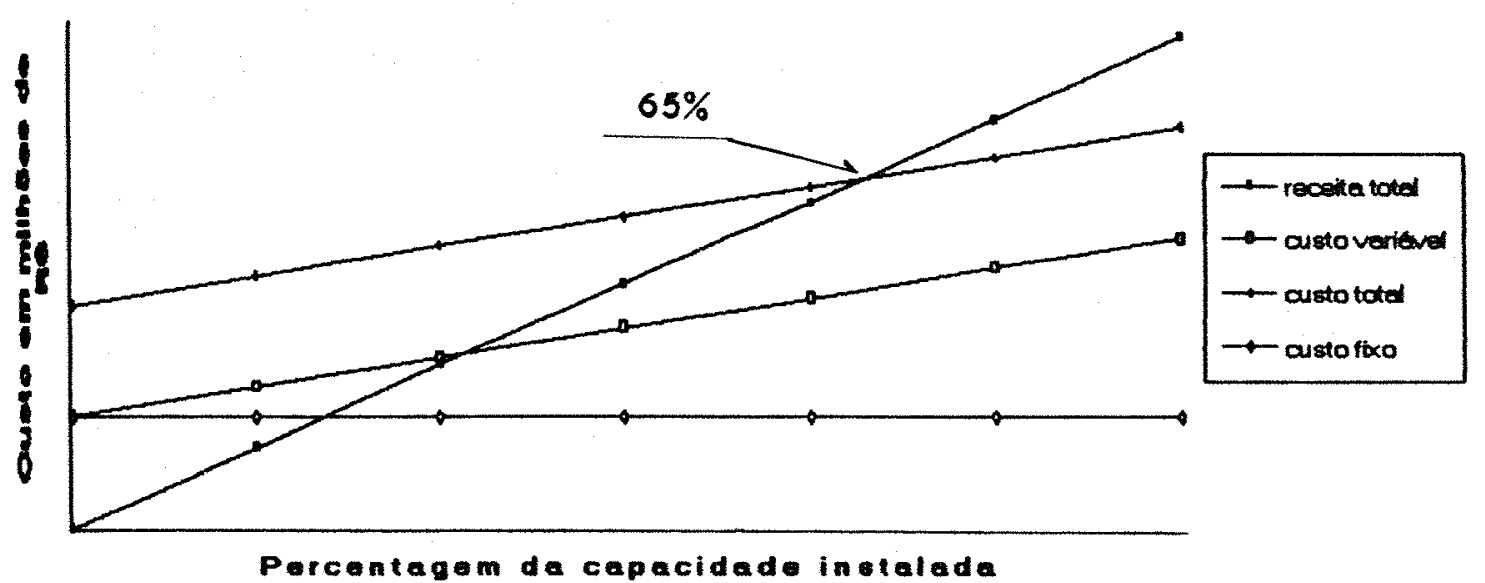

Fig. 4 


\section{5) Impacto sobre o nível de emprego e renda no município}

Todo investimento gera empregos diretos e indiretos. Os primeiros são mais fáceis de se determinar, como foi comentado no capítulo sobre a metodologia. Estimou-se que o projeto desse estudo irá gerar 53 empregos diretos entre mão-de-obra fixa e variável. Para o município, o efeito de geração de emprego indireto para trás (nas atividades agrícolas) é o mais importante. Ao se analisar a atividade agrícola propriamente dita, é possível se fazer uma estimativa da quantidade de emprego gerada nesse setor. Considerando-se uma produtividade média da cultura do maracujá no município de Vera Cruz de 21 tha e uma produção para a safra de 94/95 de 5000 t/ano, conforme estimativa da AFRUVEC, será necessária uma área de 238 ha de maracujá plantado. Mas, dessa produção, apenas $1300 \mathrm{t}$ se destinam à indústria. No entanto, se utilizar $100 \%$ da capacidade instalada da unidade industrial proposta, haverá necessidade de 4680 t/ano de matéria-prima, supondo-se que $26 \%$ da produção de maracujá seja destinada à indústria. Assim, o projeto implica numa necessidade de uma área adicional de aproximadamente 600 ha. Esse número pode ser drasticamente reduzido se ocorrer um aumento da produtividade e/ou aumentar a percentagem de fruta que se destina à indústria. Como pode ser observado nas tabelas 21 a 25, a área necessária para o plantio de maracujá pode variar de 857,1 ha a 303,3 ha, dependendo da percentagem de maracujá enviada à indústria e do nível de produtividade.

Segundo a legislação tributária do Estado de Såo Paulo sobre o suco de maracujá e de abacaxi congelados, comercializados em tambores, apenas o imposto sobre circulação de mercadorias e serviços (ICMS) incide sobre os mesmos, sendo que a aliquota corresponde a $12 \%$ do valor do produto comercializado. Dessa maneira, esses dois produtos proporcionarão uma arrecadação para o Estado, por mês, de aproximadamente RS $2.380,00$ (maracuja) e de R\$ 890,00 (abacaxi). 
Tabela 21 - Necessidade de maracujá em função da percentagem da utlizaçāo da capacidade da indústria.

\begin{tabular}{cc}
\hline \% da utilização da & $\begin{array}{c}\text { Necessidade de fruta } \\
\text { por ano (toneladas) }\end{array}$ \\
capacidade instalada & 4680 \\
100 & 4212 \\
90 & 3744 \\
80 & 3276 \\
70 & \\
\hline
\end{tabular}

Fonte: Dados de Pesquisa

Tabela 22 - Necessidade de área plantada de maracujá, em ha, em funçāo da percentagem de fruta destinada à indústria e da produtividade da cultura $\mathbf{a}$.

\begin{tabular}{rcccc}
\hline \% Iruta & \multicolumn{4}{c}{ Produtividade (Wha) } \\
\cline { 2 - 5 } p/ indústria & 21 & 23 & 25 & 27 \\
\hline 26 & 857.1 & 782.6 & 720.0 & 666.7 \\
30 & 742.9 & 678.3 & 624.0 & 577.8 \\
35 & 636.7 & 581.4 & 534.9 & 495.2 \\
40 & 557.1 & 508.7 & 468.0 & 433.3 \\
\hline
\end{tabular}

Fonte: Dados de pesquisa. a $100 \%$ da capacidade instalada da indústria

Tabela 23 - Necessidade de área plantada de maracujá, em ha, em funçāo da percentagem de fruta destinada à indústria e da produtividade da cultura ( $90 \%$ da capacidade instalada da fábrica).

\begin{tabular}{ccccc}
\hline \% Iruta & \multicolumn{4}{c}{ Produtividade (Mha) } \\
\cline { 2 - 5 } p/ indústria & 21 & 23 & 25 & 27 \\
\hline 26 & 771.4 & 704.3 & 649.0 & 600.0 \\
30 & 658.6 & 610.4 & 561.6 & 520.0 \\
35 & 573.1 & 523.2 & 481.4 & 445.7 \\
40 & 501.4 & 457.8 & 421.2 & 390.0 \\
\hline
\end{tabular}

Fonte: Dados de pesquisa.

Tabela 24 - Necessidade de área plantada de maracujá, em ha, em função da percentagem de fruta destinada à indústria e produtividade da cultura ( $80 \%$ da capacidade instalada da fábrica).

\begin{tabular}{lcccc}
\hline \% Iruta & \multicolumn{4}{c}{ Produtividade (Wha) } \\
\cline { 2 - 5 } p/ indústria & 21 & 23 & 25 & 27 \\
\hline 26 & 685.7 & 626.1 & 576.0 & 533.3 \\
30 & 594.3 & 542.6 & 499.2 & 462.2 \\
35 & 509.4 & 465.1 & 427.9 & 396.2 \\
40 & 445.7 & 407.0 & 374.4 & 346.7 \\
\hline
\end{tabular}

Fonte: Dados de pesquisa. 
Tabela 25 - Necessidade de área plantada de maracujá, em ha. em função da percentagem de fruta destinada à indústria e produtividade da cultura (70\% da capacidade instalada da fábrica).

\begin{tabular}{ccccc}
\hline \% iruta & \multicolumn{4}{c}{ Produtividade (Wha) } \\
\cline { 2 - 5 } p/ indústria & 21 & 23 & 25 & 27 \\
\hline 26 & 600.0 & 547.8 & 504.0 & 466.7 \\
30 & 520.0 & 474.8 & 436.8 & 404.4 \\
35 & 445.7 & 407.0 & 374.4 & 346.7 \\
40 & 390.0 & 356.1 & 327.6 & 303.3 \\
\hline
\end{tabular}

Fonte: Dados de pesquisa.

Segundo o presidente da AFRUVEC, a area correspondente a 238 ha diz respeito somente ao número de produtores rurais filiados à Associação. Quando se considera os outros produtores rurais da regiăo, a área plantada de maracujá poderá atingir $1000 \mathrm{ha}$. Assim, a quantidade da materia-prima dispontvel na regiăo năo parece ser um fator limitante para o projeto. No entanto, para a safra de 95/96, a AFRUVEC chegou a comercializar o maracujá enviado para uma indústria de polpa a um preço de U\$ 0,40 por kg, o que representa um aumento de $135 \%$ no preço da matéria-prima, tomando inviável qualquer projeto agroindustrial.

Segundo a AFRUVEC, em media, há necessidade de aproximadamente 4 pessoas/ha/ano entre trabalhador fixo e temporário na cultura do maracujá. Se a drea plantada de maracuja atingir 433ha (tabela 22), isto gerard 1732 empregos por ano, o que nos leva a concluir que o efeito para trás com a instalaçăo de uma agroindústria de suco de maracujá é grande, no sentido de geraçăo de emprego. 


\section{5) CONCLUSŌES}

Um primeiro ponto a se considerar a partir dos estudos revistos é que o setor agrícola atualmente é mais complexo, uma vez que a sociedade se tornou cada vez mais dinâmica. As interrelaçð̃es entre os setores se intensificaram, sendo necessário conhecê-las para melhor entender os problemas agrícolas. Dentro dessas interrelaçoes, está o papel da agroindústria como geradora de uma força motriz que provoca efeitos para trás e para frente. Para que ela venha a exercer esse papel, entretanto, é preciso antes, verificar a sua viabilidade econômica. Este foi o objetivo desse estudo com respeito à instalação de uma unidade de processamento de maracujá e de abacaxi no município de Vera Cruz, cuja capacidade instalada corresponde ao processamento de $2500 \mathrm{~kg}$ de matéria-prima por hora, valor este calculado em função da disponibilidade de matéria-prima na região. O ponto de equilibrio do projeto industrial foi calculado em $65 \%$ da capacidade instalada da fábrica.

Quando analisamos os resultados, verificamos que a TIR do caso base é de $25,72 \%$, valor esse suficiente para cobrir o custo de capital da empresa, pelo fato de que as taxas de juros cobradas pelo BNDES para empresas de pequeno porte variam de 8 a $12 \%$ a.a. No entanto, o ponto principal é conseguir matéria-prima suficiente para utilizar toda a capacidade instalada da agroindústria, pois se verificou que a TIR é altamente sensivel à variação da capacidade instalada. À medida que o volume de matéria-prima comercializado pela AFRUVEC aumenta, a viabilidade de instalação da agroindústria aumenta, pois a TIR mostrou-se bastante satisfatória. Com relação à geração de emprego, o efeito dessa unidade industrial para trás é muito grande, pois irá possibilitar a oferta de aproximadamente 1700 emprego por ano na área agrícola quando se utiliza $100 \%$ da capacidade instalada da fábrica, o que poderá contribuir para solucionar um problema grave atual, que é a falta de emprego e a consequente migraçăo rural. No entanto, não se pode afirmar que necessariamente esse projeto irá incentivar a produção agricola familiar, pois nada impede que produtores mais capitalizados venham a satisfazer a demanda da indústria por matéria-prima. Nesse sentido, a 
Associação, juntamente com outras organizaçðes ligadas ao setor rural da regiåo, poderia desenvolver programas especificos voltados aos pequenos produtores, com o objetivo de envolvê-los nesse empreendimento. A cooperaçăo de órgăos de pesquisa e extensão rural seriam imprescindiveis para tornar disponiveis (ou mesmo criar) tecnologias que possam ser adotadas pelos pequenos produtores, cujo principal fator limitante é o capital para investimento. Além disso, também é importante considerar que mesmo que os pequenos produtores venham a fornecer matéria-prima para indústria, isso não significa necessariamente que haverá um aumento na sua renda, pois existe toda uma relaçăo contratual que a principio deverá atender aos objetivos tanto dos produtores rurais como da incústria.

Quando se estuda um projeto industrial pode-se considerar a existência de três grandes partes: a existência de matéria-prima, a viabilidade econômica do projeto e a demanda pelo produto industrializado. Os resultados do presente trabalho sugerem que as duas primeiras partes năo oferecem problema. Entretanto, preços da matéria-prima como os ocorridos na última safra (US\$ $0,40 / \mathrm{kg}$ ), apontam para a necessidade de estudos que analisem o comportamento daquele preço no tempo. O conhecimento de movimentos ciclicos do preço da matéria-prima no tempo, caso existam, precisam ser incorporados à análise de viabilidade econômica da indústria. O mesmo pode ser dito com relaçăo a estudos sobre a demanda interna por suco congelados.

Este trabalho ird proporcionar aos dirigentes da AFRUVEC subsidios para a tomada de decisão no sentido de instalar ou não uma agroinctústria no municipio. Caso sejam favoráveis, deverăo planejar suas ações para atingir este objetivo, as quais deverăo incluir três pontos de um programa de fomento para a produção da matéria-prima :

a) aumentar o número de associados;

b) manter e/ou aumentar a produtividade e

c) estabelecer algum parâmetro para definir qual a percentagem da produção que se destina à indústria, no sentido de năo faltar produto quando a produçăo for de boa 
qualidade; e de não haver uma superoferta quando a produção for de má qualidade, pois o produto destinado à indústria é de qualidade inferior ao produto enviado ao mercado "in natura" (nesta última safra 94/95, devido às condições climáticas desfavoráveis, $55 \%$ da produção foi destinada à indústria).

Para medir com uma maior precisão os efeitos desse projeto de investimento na geração de empregos diretos e indiretos e na renda da região, seria interessante que futuros estudos elaborassem uma matriz regional de insumo-produto, para tentar quantificálos. 


\section{BIBLIOGRAFIA :}

AHMMED, C. S.; HERDT. R. W., Measuring the impact of consumption linkages on the employment effects of mechanization in Philippine rice production, The Journal of Development Studies, London, v.20, n.2, p.242-255, jan 1984.

ALBUQUERQUE, R. H P. L.; GARCIA, R. C., Polftica cientifica e tecnologia para o setor agroindustrial: reflexб̌es sobre a experiência brasileira. Campinas, CNPQ -NPCT- UNICAMP, 1988. 122p.

ALMEIDA, L.A.S.B., Viabilidade econômica e localização de unidades produtoras de farinha de milho para utilização em mistura com trigo no Estado de Såo Paulo, Piracicaba, 1981. 159p.(Ms. - Universidade de São Paulo).

ALMEIDA ,L.A.S.B. et alii. Batata pre-frita e hortaliças congeladas: Estudos Econdmicos Alimentos Processados, Campinas, n. 18, p1-86,1983.

ANUARIO ESTATISTICO DO BRASIL, Rio de Janeiro, FIBGE, 1981.

ARAÚJO, N. B., et alii. Complexo Agroindustrial, $O$ "Agribusiness" brasileiro. Săo

Paulo, Agroceres, 1991. 238p.

BABB, E.M, Management an financing of vertical coordination in agriculture : Discussion. American Journal Agricultural Economics, Iowa, v.74, n.5, p.1238-1239, 1992.

BAPTISTELLA. C.S.L. et alii. Valor da produção agropecuária paulista: A contribuiçăo das diferentes categorias de produtor rural. In: CONGRESSO BRASILEIRO DE ECONOMIA E SOCIOLOGIA RURAL, n. 29, Campinas, S.P., Anais. Brasilia, SOBER, 1991. p.286-322.

BARROS, G. S. C., Agricultura brasileira - desenvolvimento em perspectiva. In :

CONGRESSO BRASILEIRO DE ECONOMIA E SOCIOLOGIA RURAL, n.31. Théus, BA., Anais. Brasilia, SOBER, 1993. p.973-84. 
BARRY, P.J., et alii. Vertical coordination, financial structure, and changing theory of the firm. American Journal of Agricultural Economics, Iowa, v.74, n.5, p.12191235,1992 .

BROW, J. G. Aperfeiçoamento das agroindústrias no paises em desenvolvimento, Finanģas e Desenvolvimento, Washinton, v.6, n.2, jun. 1986.

BUSSEY, L.E. The Economy Analysis of industrial projects. London, Prentice-Hall 1980. 491p.

CANTO, W.L. et alii. Processamento e mercados de frutas secas. Estudos Econômicos Alimentos Processados, Campinas, n.23, p.1-207,1987.

CARVALHO, F. C. et alii. Avaliaçăo do potencial agroindustrial das divisðes agricolas de Araçatuba e Presidente Prudente, Estado de São Paulo. Agricultura em Sxo Paulo, Săo Paulo, v.39, supl.1, p.51-102,1992.

CASTANHO, E. P. F. Origens da agricultura industrializada. Relatório de Pesquisa. IEA, Sào Paulo, n.5, 1985.

CHIRIBOGA, M.; PLAZA, O., Desarrolo rural, microrregional y descentralizacion. Série Documentos de Programas. IICA, Costa Rica, n.32, feb.,1993.

DE PAULA, M.B.P., et alii. O custo dos recursos domésticos e a competitividade da agricultura brasileira. Relat6rio de Pesquisa. IPEA, 1994, 188p.

DAVIS, J. H.; GOLDBERG, R. A., A concept of agribusiness. Boston, Harvard University, 1957. 136p.

DOEKSEN, G.; SCHREINER, D. F., Investment in agriculture processing for rural development in Oklahoma. American Joumal of Agricultural Econommics, Iowa, v.54,n.3,p.513-24,1972.

FARINA, E. M. M. Q., O sistema agroindustrial de alimentos,In: ENCONTRO NACIONAL DE ECONOMIA,n.28, Belo Horizonte, MG. Anais. Rio de Janeiro, ANPEC 1988. v.3, p.292-315. 
FARO, C., Critérios quantitativos para avaliaçẫo e seleçăa de projetos de investimentos. Rio de Janeiro, RJ. IPEA. 1971,142p.

FEIJÓ C. A. A. V. C. et alii. Produçăo agrícola, agroindustrial e máquinas e insumos agricola nos anos 80: novas evidências estatitica. In: CONGRESSO BRASILEIRO DE ECONOMIA E SOCIOLOGIA RURAL n.28; Florianopolis, SC. Anais. Brasilia, SOBER, 1990. p.343-62.

FLORES, M. X. et. alii. Tecnologia na produçåo e industrializaçåo agropecuária, In: CONGRESSO BRASILEIRO DE ECONOMLA E SOCIOLOGLA RURAL, n.29, Campinas, SP. Anais. Brasilia, SOBER, 1991. p.764-68.

GONÇALVES, J. S. et alii. Mudanças na composição da área cultivada no Estado de Såo Paulo e suas regioes agricolas, 1970/72 e 1987/89. Informaçóes Econômicas, Såo Paulo, v.20,n.12,p. 69-92,dez.1990.

GRADILONE, C.Titulos da divida caem com o aumento dos juros nos EUA. Gazata Mercantil, Såo Paulo, 30 jan 1995.

GUILHOTO, J. J. M. Mudanças estruturais e setores chaves na economia brasileira, 1960 1990, In: ENCONTRO BRASILEIRO DE ECONOMETRIA, n.14, Campos do Jordæo, SP. Anais. Rio de Janeiro, SBE,1992. v.1, p.292-310.

HAGUENAUER, L. et alii. Os complexos incustriais na economia brasileira, Texto para discuss:7o, UFRJ, Rio de Janeiro, n.62, jul. 1988.

HESPANHOL, R. A. M; COSTA, V. M. H. M, As transformaçöes do tomate a caminho da indústria - um caso de modernizaçăo a partir da integraçăo agroindústrial. In: CONGRESSO BRASILEIRO DE ECONOMIA E SOCIOLOGIA RURAL, n.30, Rio de Janeiro, RJ. Anais, Brastlia, SOBER, 1992. p.354-73.

KAGEYAMA, A. et alii, O novo padrăo agricola brasileiro: do complexo rural aos complexos agroindustriais, In DELGADO G. C. et alii. ed, Agricultura e polfticas públicas. Rio de Janeiro, IPEA, 1990.p.113-221. 
KING, R.P. Management and financing of vertical coordination in agriculture: an overview. American Jourmal of Agricultural Economics, Iowa, v.74, p.1217-1218, 1992.

LAUSCHNER, R. Industrializaçăo dos produtos agricolas.Perspectiva Económica, Porto Alegre, v.11, n.33, p.115-168, 1981.

LAUSCHNER, R. El sector agroindustrial y el desarollo economino. Perspectiva Economica, Porto Alegre, v.21, n.54, p.7-40, 1986.

LEITE, S. Agricultura, relaçores intersetoriais e encadeamento produtivos, In: CONGRESSO BRASILEIRO DE ECONOMIA E SOCIOLOGIA RURAL, n.28, Florianópolis, SC., Anais. Brasilia, SOBER, 1990. p.61-84.

LEITE, R.S.S.F. et alii. Estudo técnico-conômico para implantaçăo de uma unidade industrial pra produçăo de cebola e pimenta desidratadas. Estudas Econômicos Alimentos Processados. Campinas, n.15, p.1-80, 1982.

LIFSCHITZ, J.; PROCHNIK, V. Observaçðes sobre o conceito de complexo agroindústrial. Texto para discussino. UFRJ, RJ. n.260, 1987.

LUCCHESI, C.P. O Mercado externo se fecha para o Brasil. Folha de Sao Paulo, São Paulo, 05 março 95.

MARTIN, N. B. O poder local e o desenvolvimento rural. Infomaçðes Econámicas, Såo Paulo, v.23, n.12, p.27-36,1993.

MARTINS, S. S. Agricultura paulista: da modernizaçăo d crise, Relatório de Pesquisa. IEA, Săo Paulo, n.6, 1986.

MULLER, G. Complexo agroindústrial e modernizacăo agraria. São Paulo, Hucitec, 1989, 148p. (Estudos Rurais).

NORONHA, J.F. Projetos agropecufirios. administraç̄oñ financeiras, orçamentos e viabilidade Econâmica. Săo Paulo, Atlas, 1987. 269p.

OLIVEIRA, J.C., Dever em real custa 56\% mais caro que em dolares. Folha de Sza Paulo, Săo Paulo, 16 agosto de 1995 
PAIVA, R. M. Os baixos niveis de renda e de salários na agricultura brasileira. In: CONTADOR, C. R. Tecnologia e desenvolvimento agricola. Rio de Janeiro, IPEA, 1975. p.195-232. (Série Monografia, n.17).

RAMALHO, Y. M. M.,coord. et alii. Mudanças estruturais nas atividades agrárias: uma análise das relações intersetoriais no complexo agroindustrial brasileiro. Rio de Janeiro, BNDESDEEST, 1988. 126p. (Estudos BNDS, 9).

SANTOS, J. A. N. Estudos sobre a agroindústria no Nordeste: as cooperativas e associações de irrigantes. Fortaleza, Secretária Nacional de Irrigação, BNB, ETENE, 1991. (BNB. Estudos Econômicos e Sociais, v.7).

SATO, G. S., et alii. Panorama da produçăo e de mercado do maracujá.Informaçđes Econômicas, Såo Paulo, v.22, n.6, p.17-31, jun. 1992.

SCARLTO, G.; RUBIO, L. La nocion de complejo agroindustrial: uma revision y reflexion para el caso uruguaio. Rascunha, Araraquara, n.18, 1991.

SENA, W. Z. Economias de escala no processamento de frutas e hortaliças: uma análise da viabilidade de implantação de agroindústrias de pequeno porte em áreas rurais, Viçosa, 1988.80p. (Ms. - Universidade Federal de Viçosa).

SILVEIRA, J. D.; LEITE, P. S. Estudos sobre a agroindústria no nordeste: a agroindústria de produtos alimentares. Fortaleza, Secretária Nacional de Irrigação, BNB, ETENE, 1990, (BNB, Estudos Econnômicos e Sociais, v.6, )

SINOPSE PRELIMINAR DO CENSO DEMOGRAFICO,Rio de Janeiro, IBGE, n. 19.1991.

SOLOMON E. ; PRINGLE J.J. Inroduçæ̃ a administraçũo financeira. São Paulo, Atlas, 1981. 525p.

SORJ, B. Estado e classes sociais na agricultura brasileira. 2.ed. Rio de Janeiro, Zahar, 1980. 152p.

STREETER, D. H. et alii, Information technology, coordination, and competitiveness in food and agribusiness sector. American Joumal of Agricultural Economics, Iowa v.73, n.5,p.1465-71,1991. 
UNIDO (Organização para Desenvolvimento Industrial das Naçđes Unidas), Manual de preparaça de estudos de viabilidade industrial. Săo Paulo, Atlas, 1987. 286p.

YOUNG, B. J.; CAMPIGLIA, A. P. B. Pólos agroindústriais, Manual da Cati. Campinas, S.P., n.34, abr.,1991.

YOUNG, L. W. Labour demand and agroindustrial development: the evidence from Mexico.

The Journal of Development Studies, Londres, v.30,n. 1, p.168-89, oct.1993. 
7. ANEXO 
Tabela 29. Lista dos Equipamentos de Laboratório para a unidade industrial



US\$1,00 = R\$0,833

$12 / 02 / 95$

Fonte: Setor Engenharia e Pesquisa do ITAL 
Tabola 31. Lista de veículos para unidade industrial

\begin{tabular}{|c|c|c|c|c|c|}
\hline Quantidade & Denominacio & $\begin{array}{l}\text { Valor } \\
\text { [R\$] }\end{array}$ & $\begin{array}{c}\text { Gós } \\
{[\mathrm{Kg} / \mathrm{h}]}\end{array}$ & $\begin{array}{l}\text { Alcool } \\
(\mathrm{km} / \mathrm{l})\end{array}$ & $\begin{array}{l}\text { Eletricidade } \\
\text { [Kwh] }\end{array}$ \\
\hline $\begin{array}{l}1 \\
1 \\
1 \\
2\end{array}$ & $\begin{array}{l}\text { Empilhadeira Clark, modelo c } 300 \mathrm{Hy}-50 \\
\text { Perua Kombi-Volkswagem, modelo Standard } \\
\text { Empilhadeira manunal elctrica, modelo BYGR-1000 } \\
\text { Paleteires, modelo BYGL-2000 }\end{array}$ & $\begin{array}{r}29842.15 \\
9822.22 \\
6341.49 \\
1865.04\end{array}$ & 4.0 & 10.0 & 4.0 \\
\hline & Total & 47870.90 & & & \\
\hline
\end{tabular}

US\$1,00 = R\$0,833

$12 / 02 / 95$

Fonte: Setor Engenharia o Pesquisa do ITAL 
Tabele 32. Lista de móveis e instalaçóses de escritório.

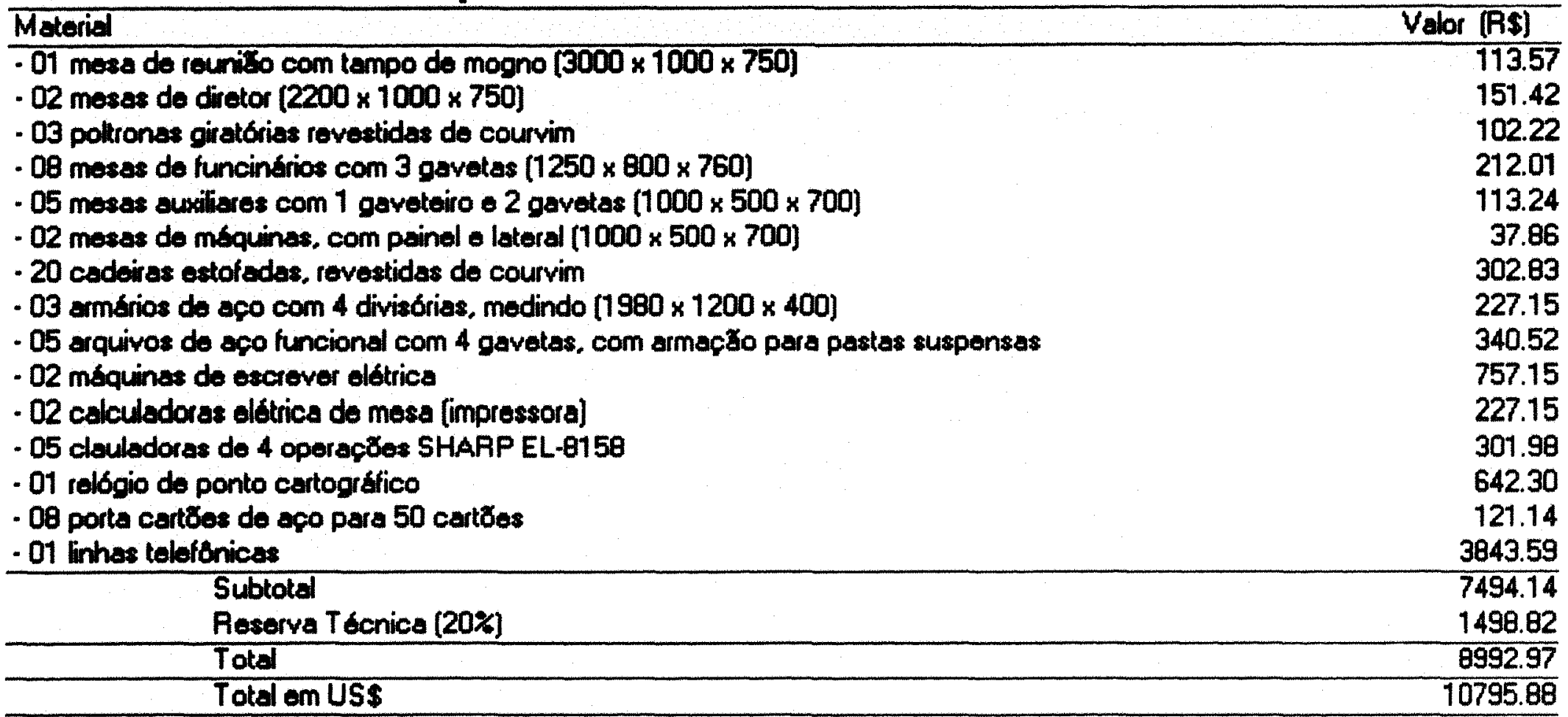

US\$1,00 - R\$0,833

$12 / 02 / 95$

Fonte: Setor Engenharia e Pesquisa do ITAL 
Tabela 33. Estimativa de m8o de cbra fixa mensal

\begin{tabular}{|c|c|c|}
\hline Quentidade & Funço & Valor (A\$) \\
\hline 1 & Engenheiro de processo para supervisso da producso e dieço geral & 883.58 \\
\hline 2 & Nivel médio responsavel pelo túnel de congelamento e estocagem frigorificada & 419.70 \\
\hline 1 & Nivel médio responsével pelo processamento dos sucos congelados & 419.70 \\
\hline 2 & Controladores de estoque de insumos, materia-prima e produtos acabados & 618.51 \\
\hline$\overline{1}$ & Mecenicos de manutença & 287.1 \\
\hline 1 & Eletricistas de manutença & 309.25 \\
\hline 1 & $\begin{array}{l}\text { Responsável pela caixa d'bgua, torre de resfriamento, } \\
\text { titema hidrádulico espoto }\end{array}$ & 265.07 \\
\hline 1 & Responsóvel pelo sistema de frio da fábrica & 371.10 \\
\hline 1 & Nivel módio - Chefe de laboratório & 375.52 \\
\hline 1 & Contador/caixa & 397.61 \\
\hline 1 & Recepcionista/telefonista & 132.54 \\
\hline 1 & Datilografa/secretária & 132.54 \\
\hline 1 & Expedidor de faturas e operador de arquivos & 154.6 \\
\hline 1 & Porteiro & 130.33 \\
\hline 2 & Vigies & 265.07 \\
\hline 2 & Coldeiristas & 530.15 \\
\hline 4 & Faxineiros & 353.43 \\
\hline 1 & Motorista de empilhadeira & 220.8 \\
\hline 2 & Motoristas de veículos & 397.61 \\
\hline 1 & Jardineiro & 128.11 \\
\hline 1 & Office-boy & 36.80 \\
\hline & Total & 6829.3 \\
\hline & Total em US\$ & 8198.5 \\
\hline
\end{tabular}

Fonte: Folha de S8o Paulo - Bolsa de Salarios - janeiro/95 
Tabela 34. Estimativa de mão de obra variável mensal (folha mensal)

\begin{tabular}{lc}
\hline Função & $\begin{array}{c}\text { Numero } \\
\text { de Operários }\end{array}$ \\
\hline 1. Industrialização do suco de abacaxi congelado & 3 \\
- Recepção estocagem da matéria-prima & 2 \\
- Alimentadores do lavador & 6 \\
- Descascamento de frutas & 1 \\
- Operador do deseintegrador & 1 \\
- Operador do Yinisher" & 1 \\
- Operador do pasteurizador/resfriador & 3 \\
- Operadores do enchimento de tambores & 2 \\
- Fechadores dos tambores e latas & 2 \\
- Ajudantes & 3 \\
Total & 24
\end{tabular}

2. Industrialização do suco de maracujá congelado

- Recepção, e estocagem da matéria-prima 3

- Alimentadores do lavador 2

- Operador do despolpador 6

- Operador do "finisher" 1

- Operador do pasteurizador/resiriador 1

- Operadores do enchimento de tambores 2

- Fechadores dos tambores 2

- Paletizadores 2

- Ajudantes 3

Total $\quad 24$

Salário Minimo $R \$ 70,00$

Total da Folha Mensal para o suco de Abacaxi $\quad 1.680,00$

Total da Folha Mensal para o suco de Maracujá $\quad 1.680,00$

Fonte: Folha de São Paulo - Janeiro/95 